\title{
The Ecology of Corporate Governance in China
}

Donald C. Clarke

George Washington University Law School, dclarke@law.gwu.edu

Follow this and additional works at: https://scholarship.law.gwu.edu/faculty_publications

Part of the Law Commons

\section{Recommended Citation}

Clarke, Donald C., "The Ecology of Corporate Governance in China" (2008). GW Law Faculty Publications \& Other Works. 1065.

https://scholarship.law.gwu.edu/faculty_publications/1065

This Article is brought to you for free and open access by the Faculty Scholarship at Scholarly Commons. It has been accepted for inclusion in GW Law Faculty Publications \& Other Works by an authorized administrator of Scholarly Commons. For more information, please contact spagel@law.gwu.edu. 


\title{
The Ecology of Corporate Governance in China
}

\author{
Donald C. Clarke*
}

Aug. 29, 2008

\begin{abstract}
The substantive norms of Chinese corporate governance have been studied extensively inside and outside China. Yet much less attention has been paid to the Chinese institutional environment that determines whether and how far those norms will be made meaningful. While complaints about general lack of enforcement are common, less common are analyses that concretely tie institutional capacity to specific enforcement problems. This article aims to fill that gap. It surveys a number of state and non-state channels for the enforcement of corporate governance rules and standards in China, from markets to regulatory bodies, looking at the specific capacities of each. It concludes by finding that while the state for political reasons prefers to leave enforcement to state regulatory bodies, its repression of civil society institutions is so severe that even a modest relaxation could have substantial benefits.
\end{abstract}

* Professor of Law, George Washington University Law School. I am grateful for the help I received from a number of people in the course of researching and writing this article. In particular. thanks are due to Knut Benjamin Pissler, Larry Ribstein, Tang Xin, and Frank Upham for their ideas and support, Annie Liu, Katie Reece, and Huang Nian for research assistance, and faculty workshops at Yale University School of Management, New York University School of Law, Hong Kong University Faculty of Law, and Cornell University School of Law for development of the ideas. 


\section{TABle of Contents}

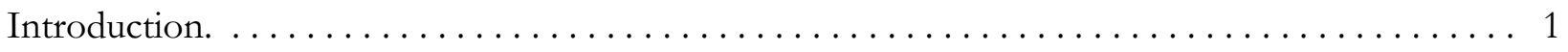

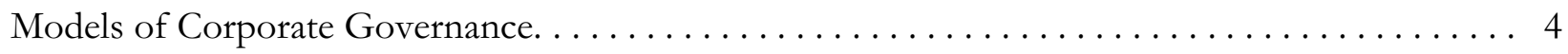

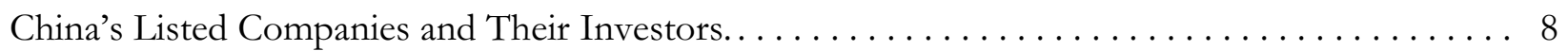

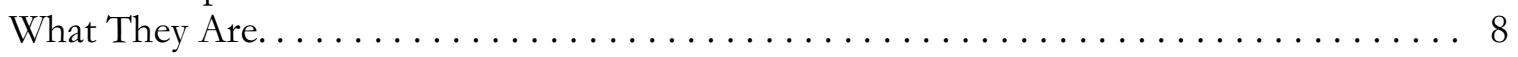

Where They Come From. . . . . . . . . . . . . . . . . . . . . 8

Introduction to the Traditional State-Owned Enterprise. . . . . . . . . . . . 8

Early Efforts at Reform of the TSOE and the Corporatization Policy. ........ 9

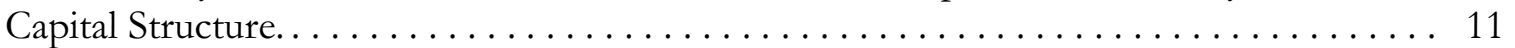

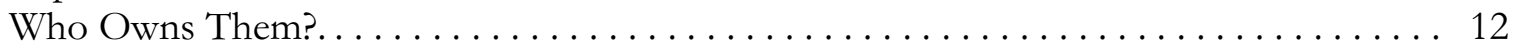

Institutions of Corporate Governance in China. . . . . . . . . . . . . . . . 14

The Role of Stock Markets and External Debt in Corporate Finance and Corporate

Governance. ..................................... 15

Historical Background............................. 16

The Stock Market in Recent Years. . . . . . . . . . . . . . . . . . . . . 17

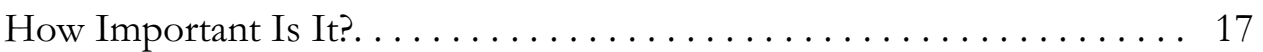

Characteristics of Investors. . . . . . . . . . . . . . . . . . 19

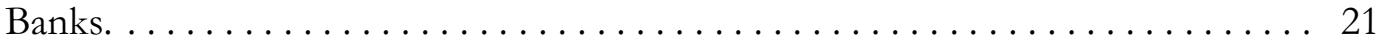

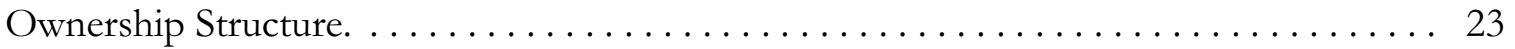

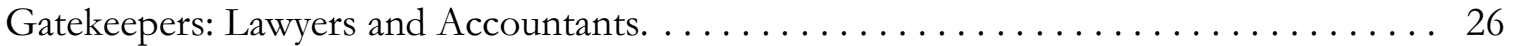

Accounting Firms as Gatekeepers. . . . . . . . . . . . . . . . . . . . . . . 27

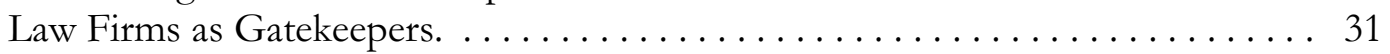

State Institutions for Corporate Governance (I): The Role of the CSRC . . . . . . . . 32

Regulatory Authority........................... 32

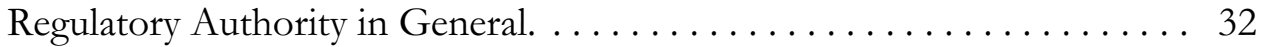

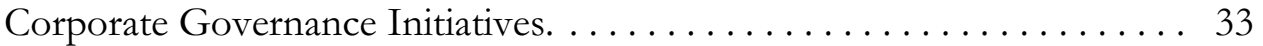

Enforcement Tools. ................................ 36

Refusal to Approve Applications for Stock Issuance. . . . . . . . . . . . 36

Refusal to Accept Applications for Stock Issuance or Other Matters. . . . 37

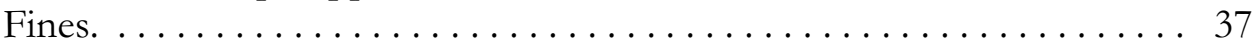

Banning from the Market........................ 37

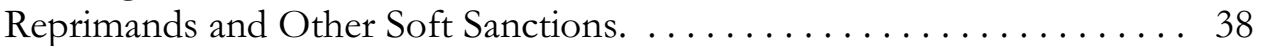

"Comply or Explain". . . . . . . . . . . . . . . . . . . . . . . . . 39

Summary: What Role Can the CSRC Play in Corporate Governance?.. . . . . . . . 40

State Institutions for Corporate Governance (II): The Stock Exchanges. . . . . . . . . . . 42

State Institutions for Corporate Governance (III): The Court System. . . . . . . . . . . 43

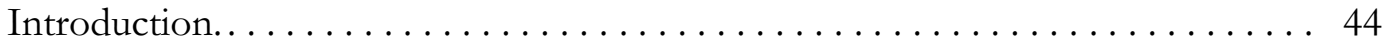

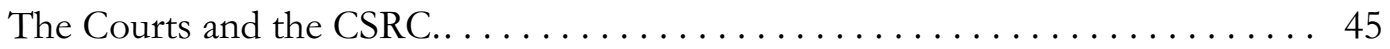

Shareholder Derivative Suits. . . . . . . . . . . . . . . . . . . 47

Doctrinal Bases............................. 48

1993 Company Law. . . . . . . . . . . . . . . . . . . 48

1999 Securities Law. . . . . . . . . . . . . . . . . . . . . 49

Principles of Corporate Governance for Listed Companies. . . . . 50

2004 Beijing Higher People's Court Opinion.. . . . . . . . . . . . . . 50 
Supreme People's Court Policy. . . . . . . . . . . . . . . . . 51

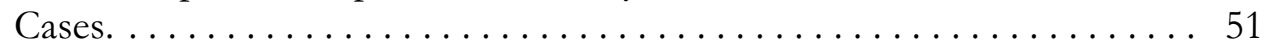

Zhangjiagang Fiber Company Case.. . . . . . . . . . . . 52

Shanghai Yanzhong Water Company Cases. . . . . . . . . . . 52

Xiamen Xinda Network Company Case................. 53

Zhejiang Wu Fang Zhai Company Case................ 53

San Jiu Pharmaceutical Company Case................ 54

Derivative Suits in the New Company Law.. . . . . . . . . . . . . . . . 54

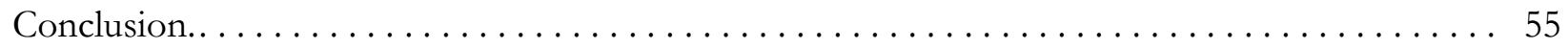




\section{INTRODUCTION}

Chinese corporate governance presents many puzzles. Controlling blocks of stock have historically sold at a vast discount, not a premium, to the stock market price. China gets a perfect score on a widely used shareholder-rights index, ${ }^{1}$ yet looting seems widespread. ${ }^{2}$ The securities regulator fears that cracking down on abuses will stifle, not stimulate, financial markets.

Policymakers view the separation of ownership from control in large corporations not as a problem to be solved but as a solution to be embraced. The leading proponent of independent directors as a defense against abuses by controlling shareholders is none other than China's main controlling shareholder, the state. And underlying it all is a legislative system that observers describe using terms such as "chronic disorder" ${ }^{3}$ and "chaos."

Something interesting is going on here. The assumptions and institutions behind corporate governance in China must be quite different from the assumptions and institutions of corporate governance in Western economies. Yet the discussion of Chinese corporate governance-and indeed, a major body of literature on comparative corporate governance-often focuses on the substantive rules and seems to assume that the institutional environment within which the rules operate is pretty much the same everywhere. The differences are hardly acknowledged, let alone thoroughly analyzed.

Of course, to state that the law cannot be studied in isolation from the institutions by which it is made and enforced can hardly be considered controversial. Nobody will get tenure by pointing out that in the United States, for example, both the norms of securities law and the means of their enforcement are inseparable from the regulatory capacity of the Securities and Exchange Commission. American securities law would look very different without the army of private-sector lawyers and other intermediaries that it relies on to function. ${ }^{5}$

Yet even in a country such as the United States, where the institutional context of legal rules is well understood at least at an intuitive level by insiders, scholarship can make an important contribution to understanding how institutions shape the making and enforcement of legal rules. ${ }^{6}$

${ }^{1}$ See R. La Porta, F. Lopez-de-Silanes, A. Shleifer \& R.W. Vishny, Law and Finance, 106 J. Polit. ECON. 1113, 1130 (1998).

2 See, e.g., Yi Zhang, Law, Corporate Governance, and Corporate Scandal in an Emerging Economy: Insights from China (Nov. 2007), available at http://ssrn.com/abstract=957549; Ming Jian \& T. J. Wong, Earnings Management and Tunnelling Through Related Party Transactions: Evidence from Chinese Corporate Groups (June 2003), available at http://ssrn.com/abstract $=424888$.

${ }^{3}$ See Perry Keller, Sources of Order in Chinese Law, 42 Am. J. Comp. L. 711, 712 (1994).

${ }^{4}$ See Randall Peerenboom, China’s Long March Toward Rule of Law ch. 6 (2002) (entitled "The Legislative System: Battling Chaos").

${ }^{5}$ This is not, of course, to say that the system always produces the desired results. See, e.g., John C. Coffee, Jr., Understanding Enron: "It's About the Gatekeepers, Stupid", 57 Bus. Law. 1403 (2002). It is just to emphasize that the significance of a norm is inseparable from its institutional context.

${ }^{6}$ Different perspectives on this issue can be found in, among many others, NEIL K. Komesar, Imperfect Alternatives: Choosing Institutions in Law, Economics, and Public Policy 
The Chinese institutional context is by contrast far less well understood and studied, even by insiders; the payoff to examining it, therefore, is even greater. And it is not enough just to agree in the abstract with the proposition that institutions matter; the interesting work lies in actually figuring out which institutions matter, and how much, and why (or why not).

While Chinese corporate governance has become an increasingly popular subject of study both in China and outside of it, studies emphasizing the role of institutions in making the norms meaningful are rare. ${ }^{7}$ This article aims to fill that gap — not just by arguing that institutions matter in the abstract, but by showing how specifically they matter in China, and what would have to change for the institutions to matter in a different way. This complexity is of course not unique to China, but is perhaps at least more apparent there.

This article also aims to demonstrate, through its case-study approach, the dangers of a prominent branch of comparative corporate governance scholarship-the so-called "LLSV" literature ${ }^{8}$ and its offshoots - that is dedicated to measuring the legal norms of corporate governance and correlating those measurements to measurements of financial market development and economic development more generally. This literature has been criticized on several grounds: that it focuses too much on substantive law on the books and ignores enforcement issues; ${ }^{9}$ that when it does look at enforcement issues, it again looks just at law on the books; ${ }^{10}$ that its understanding of the law-even just on the books - is often simply wrong or inconsistent; ${ }^{11}$ and that the correlations

(1994); Katharina Pistor \& Chenggang Xu, Incomplete Law, 35 N.Y.U. J. INT’L L. \& POL. 931 (2003); Louis Kaplow, Rules Versus Standards: An Economic Analysis, 42 Duke L.J. 557 (1992); Reinier Kraakman, Gatekeepers: The Anatomy of a Third-Party Enforcement Strategy, 2 J. L. Econ. \& ORG. 53 (1986); Bernard Black, The Legal and Institutional Preconditions for Strong Securities Markets, 48 U.C.L.A. L. REV. 781 (2001); and Howell E. Jackson and Mark J. Roe, Public and Private Enforcement of Securities Laws: Resource-Based Evidence (Feb. 22, 2008), available at http://ssrn.com/abstract=1000086.

${ }^{7}$ An excellent exception is Benjamin L. Liebman \& Curtis J. Milhaupt, Reputational Sanctions in China's Securities Market (June 8, 2007), available at http://ssrn.com/abstract=999698.

${ }^{8}$ The key articles forming the foundation of this literature are R. La Porta, F. Lopez-de-Silanes, A. Shleifer \& R.W. Vishny, Legal Determinants of External Finance, 52 J. FIN. 1131 (1997) and, perhaps more importantly, La Porta et al., supra note 1.

9 See John C. Coffee, Jr., Law and the Market: The Impact of Enforcement, 156 U. PA. L. REv. 229, 25051 (2007).

${ }^{10}$ See Coffee, supra note 9, at 244, 250-51.

${ }^{11}$ See Udo C. Braendle, Shareholder Protection in the USA and Germany-On the Fallacy of LLSV (May 2005), available at http://ssrn.com/abstract=728403; Robert Schmidbauer, On the Fallacy of LLSV Revisited_Further Evidence About Shareholder Protection in Austria and the United Kingdom (February 2006), available at http://ssrn.com/abstract=913968; Holger Spamann, On the Insignificance and/or Endogeneity of La Porta et al.'s "Anti-Director Rights Index” Under Consistent Coding 68 (John M. Olin Ctr. for Law, Econ. \& Bus., Fellows' Discussion Paper Series, Discussion Paper No. 7, March 2006), available at http://tinyurl.com/yuk552. 
it finds are spurious. ${ }^{12}$ While one case study cannot demonstrate conclusively that attempts to measure and compare legal rules across jurisdictions are doomed to failure, it can certainly show that truly understanding a given jurisdiction's legal system probably requires more than the already Herculean efforts for which the LLSV literature must be given credit.

Part II sets forth this article's conception of corporate governance and various ways of modeling regulatory regimes. It argues that any model must have the capacity to incorporate choices not made in order to understand better the choices that were made. It then discusses some idealtypical models that are useful in understanding Chinese institutions.

Part III provides background information on Chinese listed companies and their investors that is necessary for understanding the sometimes surprising features of Chinese corporate governance.

Part IV, the heart of this article, surveys and discusses in detail several important institutions for the implementation of corporate governance rules. The analysis focuses on the role that particular institutions are or might be called on to play, and their capacity for performing as expected. In addition to covering institutions such as the stock markets, lawyers and accountants, and the financial press, it looks in detail at the role played by the China Securities Regulatory Commission and by the courts. Part V ties the threads of this article together and offers a conclusion.

The theme that emerges from this analysis of state and civil-society institutions is that the corporate governance regime in China relies heavily on the announcement of rules by government authorities and relatively little on institutions for making those rules meaningful. Lawmakers expect that regulated parties will read the legal texts and voluntarily obey; if they do not, their ignorance or moral failings are blamed, not the lack of enforcement institutions. ${ }^{13}$

Still less does the corporate governance regime look to non-governmental institutions for the making and enforcement of rules and standards. A major reason for this is simply political: the government does not yet accept the existence of institutions that are both powerful and independent of the state. Moreover, the official cultures of both Imperial China and China under the planned economy have left their common legacy: it is hard for state officials to accept that civil society might come up with a better set of procedures than they could come up with themselves.

Yet in relying on the state legal and administrative system to make and enforce norms, the state is playing a weak card. The post-Mao Chinese legal system, despite a quarter century of change, remains an institution of only modest importance in the polity. As a result, with state

\footnotetext{
${ }^{12}$ See Mark D. West, Legal Determinants of World Cup Success (John M. Olin Ctr. for Law \& Econ., Paper No. 02-009, 2002), available at http:/ / ssrn.com/abstract $=318940$.

${ }^{13}$ It has been argued that Delaware's corporate law jurisprudence—although not its statutes—also contains this didactic element. See Edward B. Rock, Saints and Sinners: How Does Delaware Corporate Law Work?, 44 U.C.L.A. L. REV. 1009 (1997); William T. Allen, Modern Corporate Governance and the Erosion of the Business Judgment Rule in Delaware Corporate Law 14 (CLPE Research Paper 06/2008), available at http://ssrn.com/abstractid=1105591. An important difference is that Delaware expects corporate managers to educated through the medium of the corporate bar, whereas the corporate bar in China is not expected to, and does not, play this role.
} 
institutions not working well and civil-society institutions not allowed to work well, many areas of Chinese corporate governance display an astonishing enforcement vacuum.

\section{Models of Corporate Governance}

This article deals with corporate governance in China's listed companies. I use a relatively narrow concept of corporate governance. It is concerned with issues of finance and agency cost and has a policy component: the prevention of the exploitation of those who supply the money by those who control it. ${ }^{14}$ This concept centers on the relationship between stockholders, the board of directors, and senior management, and in effect asks, " $[\mathrm{H}]$ ow can financiers be sure that, once they sink their funds [into a firm], they get anything but a worthless piece of paper back from the manager?" 15

This limited conception of corporate governance has two main agency problems: vertical (the exploitation of stockholders as a whole by management) and horizontal (the exploitation of minority shareholders by controlling shareholders). In each case, the controller extracts private benefits, ${ }^{16}$ but can do so in different ways, and the means of mitigating such exploitation are different. Moreover, mitigating one kind of agency cost may mean increasing the other. Dispersed shareholding, for example, can lead to high vertical agency costs, because collective-action problems make it hard for shareholders to monitor management. But one solution-concentrated shareholdings—may result in higher horizontal agency costs. ${ }^{17}$

In the United States, the main agency cost problem is vertical; in the rest of the world, however, and especially in transition economies, horizontal costs dominate. ${ }^{18}$ China seems to be no exception to this pattern. What is exceptional, however, is the identity of the controlling shareholder that is engaging in the exploitation: in most cases, it either is or is closely connected to a governmental entity.

Commentators in the field of comparative corporate governance have proposed various models of regulation in general and corporate governance and securities regulation in particular.

\footnotetext{
${ }^{14}$ See generally Michael Jensen \& William Meckling, Theory of the Firm: Managerial Behavior, Agency Costs, and Ownership Structure, 3 J. FIN. ECON. 305 (1976).

${ }^{15}$ Andrei Shleifer \& Robert Vishny, A Survey of Corporate Governance, 52 J. FIN. 737, 740-41 (1997).

${ }^{16}$ See Mark J. Roe, The Institutions of Corporate Governance 2 (Harvard University, John M. Olin Center for Law, Economics, and Business Discussion Paper No. 488, Aug. 2004), available at http://ssrn.com/abstract $=612362$.

${ }^{17}$ See id. at 4.

${ }^{18}$ See Rafael La Porta et al., Corporate Ownership Around the World ( Harvard Institute of Economics, Research Paper No. 1840, Aug. 1998), available at http://ssrn.com/abstract=103130 ("TT]he central agency problem in large corporations around the world is that or restricting expropriation of minority shareholders by controlling shareholders[.]"); Roe, supra note 16, at 2-3; see also the literature summarized in Diane K. Denis \& John J. McConnell, International Corporate Governance, $38 \mathrm{~J}$. Fin. \& QuAntitative ANALYsis 1 (2003). For a vivid account of controlling shareholder shenanigans in Russia, see Bernard Black et al., Russian Privatization and Corporate Governance: What Went Wrong?, 52 STAN. L. REV. 1731 (2000).
} 
Paredes posits an essentially binary model in which the choice is between enabling (and possibly even trivial ${ }^{19}$ ) law à la Delaware and a mandatory regime, "in which a fixed set of typically more restrictive rules would be imposed on companies, reflecting a 'one-size-fits-all' approach to regulating corporate governance." ${ }^{20}$

In a series of articles, Pistor and Xu have also proposed a binary model, but along a different dimension: they present the choice as between ex ante regulation by administrative agencies and ex post regulation by courts. ${ }^{21}$ As they show, legal rules necessarily need filling out in many specific cases, and whether this filling-out power should be allocated to regulatory agencies or to courts is by no means self-evident. The same applies to enforcement powers; the capacity of different institutions to monitor and enforce will vary with the issue in question, and as Neil Komesar has shown, the question of relative institutional capacity is critical. ${ }^{22}$

Moreover, a recent survey by Jackson and Gkantinis of real-world models of securities regulation leads to the surprising finding that extensive state involvement in rule-making does not necessarily mean extensive state involvement in rule enforcement. ${ }^{23}$ John Coffee summarizes the results thus: "[E]nforcement intensity seems inversely related to the intrusiveness of the government's ex ante involvement in the market. The closer the central government supervises ex ante, the less it relies on sanctions and penalties ex post." 24

All these ways of modeling a regulatory regime are based on real-world observation. While this has obvious virtues, one drawback is that it makes it difficult to see foreclosed possibilities and to understand why they were foreclosed. In understanding China's institutional choices and where

${ }^{19}$ See Bernard S. Black, Is Corporate Law Trivial? A Political and Economic Analysis, 84 Nw. U. L. REV. 542 (1990).

${ }^{20}$ Troy A. Paredes, A Systems Approach to Corporate Governance Reform: Why Importing U.S. Corporate Law Isn't the Answer, 45 WM. \& MARY L. REV. 1055, 1077 (2004).

${ }^{21}$ See Katharina Pistor \& Chenggang Xu, Incomplete Law, 35 N.Y.U. J INT’L L. AND PoL. 931 (2003); see also Katharina Pistor \& Chenggang Xu, Fiduciary Duties in Transitional Civil Law Jurisdictions: Lessons from the Incompleteness of Law Theory, in Global MARKETS, DOMESTIC InSTITUTIONS: Corporate Law ANd Governance in a New Era of Cross-Border Deals 77 (Curtis Milhaupt ed., 2003); Katharina Pistor \& Chenggang Xu, Law Enforcement Under Incomplete Law: Theory and Evidence from Financial Market Regulation (April 2003), available at http://ssrn.com/abstract=396141; Katharina Pistor \& Chenggang Xu, Governing Stock Markets in Transition Economies: Lessons from China, 7 AM. L. \& ECON. REV. 184 (2005).

${ }^{22}$ See generally KOMESAR, supra note 6.

${ }^{23}$ See Howell E. Jackson \& Stavros Gkantinis, Markets as Regulators: A Survey 27 (John M. Olin Ctr. for Law, Econ. \& Bus., No. 579, Jan. 2007), available at http://ssrn.com/abstract=960168. One of the authors separately develops the concept of enforcement intensity in Howell E. Jackson, $V$ ariation in the Intensity of Financial Regulation: Preliminary Evidence and Potential Implications (John M. Olin Ctr. for Law, Econ. \& Bus., Discussion Paper No. 521, Aug. 2005), available at http:/ / tinyurl.com/3dgcsn.

${ }^{24}$ Coffee, supra note 9, at 257. 
reform is or is not possible, therefore, we need to keep in mind the options that were not selected as well as those that were.

First, the rules could be made by either or both of the state or market participants (via contract). The Pistor-Xu model does not distinguish, for example, between ex post court enforcement of mandatory state-made rules and ex post court enforcement of private contractual arrangements.

Second, the state could choose to enforce either or both of its own rules or the rules made by market participants (through enforcement of contracts); we must also leave open the possibility that the state could, through choice or institutional incapacity, not enforce anyone's rules. The Paredes model, however, assumes that whether mandatory rules or default rules are chosen, the state has the capacity to enforce them. Enforcement by the state also involves choosing enforcement institutions and the degree to which enforcement will be ex ante (for example, by state vetting of independent director candidates) or ex post (for example, by punishing directors who approve of conflict-of-interest transactions that damage the company).

If the state monopolizes rule-making power, it must be sure to get the rules right. The demands on a regime that leaves rule-making to the market are lower: participants in the corporate enterprise may contract for the rules of association that they think best for themselves. But these contracts may be quite complex, and not every country will have a court system able to enforce them. ${ }^{25}$ Thus, we cannot know a priori whether a corporate governance regime should rely on private contracts, laws enforceable by courts in private litigation, or regulations enforced by government administrative agencies. It is an empirical question. ${ }^{26}$

Third, to the extent that corporate governance is left to market participants and not monopolized by the state, one can posit three ideal-typical models - the ownership approach, the shareholder rights approach, and the market monitoring approach — that operate to mitigate agency costs, understanding that any actual jurisdiction will typically display a mix. These approaches may still, of course, require the presence of the state as an enforcer of institutional arrangements; as Black and Krakman have acknowledged, even "self-enforcing" corporate governance rules ${ }^{27}$ will still be ineffective if enforcement institutions are so weak that corporate insiders may ignore them with impunity. ${ }^{28}$

When there is concentrated ownership and it pays the dominant shareholder to expend resources in monitoring because it will reap all or most of the benefit, the incentives of ownership itself can be relied on mitigate agency costs. This kind of monitoring relies neither on minority shareholder rights nor on market signals to discipline management; the owner is already in charge and does not need the help of courts, and it can receive from its own analysis the signals that would otherwise be transmitted by the market.

${ }^{25}$ See Rafael La Porta et al., Investor Protection and Corporate Governance, 58 J. FIn. ECON. 3, 7 (2000).

26 See id.

${ }^{27}$ See Bernard Black \& Reinier H. Kraakman, A Self-Enforcing Model of Corporate Law, 109 HARV. L. REV. 1911 (1996).

${ }^{28}$ See Black et al., supra note 18. 
The ownership approach does not, however, come free. It cannot avail itself of the benefits of widely dispersed ownership, so companies too large for any single owner to control cannot use this governance method. And to the extent the owner undertakes its own analysis instead of relying on market signals, it must expend resources instead of free-riding on the activity of others.

Finally, while concentrated ownership can mitigate one set of agency costs-vertical, between managers and shareholders as a body-it can exacerbate another set-horizontal, between dominant shareholders and minority shareholders. As the former decrease, the latter may increase. Which effect will dominate the other cannot be known a priori.

The shareholder rights approach attempts to solve the problems of minority shareholders who cannot avail themselves of ownership rights; they have neither the rights nor the incentives of owners. If minority shareholders get help from the legal system at an acceptable cost, however (including the cost of informing themselves), they can protect their interests and both correct and deter management misbehavior.

Like the ownership approach, however, this approach has its characteristic costs. As the power of shareholders to protect their legitimate rights increases, so does their power to pursue illegitimate claims. A corporation whose shareholders enjoy a generous panoply of rights is a paralyzed corporation. Investors thus rationally forgo certain rights they might like for themselves because they know that other investors are similarly constrained. The key is to strike the right balance. Where that balance should be struck will differ across jurisdictions, because the availability of substitutes for forgone rights will differ. If there is a good substitute for minority shareholder rights, then there is little reason to pay the cost of an extensive complement of rights because the marginal benefit thereby purchased will be small.

This consideration leads to a third approach to corporate governance: the market monitoring approach. A firm operates in a number of markets that impose constraints on its management. Most obviously, for example, the stock market and not management has the final word on the appropriate value of a company's stock. ${ }^{29}$ When markets are functioning well, monitoring is much simpler. If stockholders wish to judge whether the CEO's salary is excessive, for example, they can look at salaries in comparable companies.

Of course, knowing that a CEO is paid too much is not the same as being able to do something about it, so the existence of a managerial labor market is not a complete corporate governance solution. But if the stock market shares this knowledge, then the stock price is discounted accordingly, and those who buy after this knowledge is incorporated into the stock price are not harmed by it. Thus, the small investor can free-ride off the valuation efforts of market professionals, and to the extent that the stock market effectively disciplines managers (and dominant shareholders if management does their bidding), the small investor needs no special protections.

${ }^{29}$ Except, it must be admitted, in litigation in which corporate value is an issue; here judges have the last word and are often reluctant simply to accept market valuations. 


\section{China’s Listed Companies And Their Investors}

\section{A. What They Are}

This article is concerned mainly with China's institutions for corporate governance as they affect the over 1,600 companies listed on one of the country's two stock exchanges in Shanghai and Shenzhen. ${ }^{30}$ We must therefore understand something about the companies themselves, because they are in many ways unlike companies listed on stock exchanges in the West or in other developing countries.

In order to be listed, a firm must have the legal form of a joint stock company (JSC) under the Company Law. A JSC must, unless established through the transformation of a traditional stateowned enterprise, have at least five initial promoters and shareholders. Until the 2005 revisions to the Company Law, it was required to have registered capital (an initial equity investment that cannot be withdrawn) of at least ten million yuan (five million yuan following the revisions). ${ }^{31}$ JSCs must have a board of directors and a board of supervisors (jianshi hui). The shareholders' meeting is made the highest organ of power within the company and has a stronger position relative to directors than in the United States. The Company Law nevertheless contemplates a relatively active role for the board of directors, with an ill-defined supervisory role for the board of supervisors.

\section{B. Where They Come From}

As most listed companies were originally state-owned enterprises in a different organizational form, ${ }^{32}$ some background about the traditional state-owned enterprise (TSOE) is necessary.

\section{Introduction to the Traditional State-Owned Enterprise}

The most important form of economic organization in the history of the People's Republic of China, the TSOE is not simply another name for a corporation such as Air France that happens to be wholly owned by the state. Instead, it can be viewed as a division within the loosely organized

${ }^{30} 1,607$ as of June 30, 2007. English-language statistics are available at the CSRC's Web site at http://www.csrc. gov.cn/en/homepage/index_en.jsp.

${ }^{31}$ At the exchange rate prevailing during the twelve years the provision was in effect, 10 million yuan amounted to about $\$ 1.28$ million. During this period, the minimum capitalization required for companies of this kind in the OECD countries was far less: about $\$ 42,000$ in Germany, and in Delaware, of course, nothing at all.

${ }^{32}$ Almost 90 percent of listed companies at the end of 2000 were originally TSOEs, see On Kit Tam, Ethical Issues in the Evolution of Corporate Governance in China, 37 J. Bus. ETHICs 303, 305 (2002), and a 2003 study concluded that approximately $84 \%$ of listed companies were, viewed solely from the standpoint of equity ownership and not taking account of informal mechanisms of influence, directly or indirectly under state control, see Guy S. Liu \& Pei Sun, Identifying Ultimate Controlling Shareholders in Chinese Public Corporations: An Empirical Survey 2 (Royal Institute of International Affairs, Asia Programme Working Paper No. 2, 2003). This figure is roughly consistent with the conclusions of other analysts. See Carl E. Walter \& Fraser J.T. Howie, Privatizing China: The Stock Markets and Their Role in Corporate Reform 137 (John Wiley \& Sons 2003) (citing 2002 Chinese study). 
firm of China, Inc. As such, it has managers that can move up a hierarchy into progressively more politically powerful positions - this is the career track of many of China's current leaders-but has nothing that could be characterized as stock or transferable equity interests.

TSOEs were not and are not necessarily all owned by the same administrative body representing the central state. Instead, the term can be applied to enterprises controlled by one or more units of government at or above the county level. The power of management and control over output - as well as responsibility for supplying inputs - could thus rest in any of one or several bodies with divergent interests and goals. Thus, if we insist on speaking of "state" ownership or "state" control of enterprises, we must conceptualize the state as an entity that is capable of pursuing contradictory and inconsistent policies.

\section{Early Efforts at Reform of the TSOE and the Corporatization Policy}

Although the diagnosis varies, there is little doubt that TSOEs were viewed by policymakers at the beginning of the era of economic reform as plagued by sloth, inefficiency, and waste. The traditional TSOE was not motivated by profit - a sensible approach, since profits in a planned economy simply reflect the difference between the economically meaningless prices of inputs and outputs. But there was little pressure on managers to economize, and their income was unconnected to firm performance.

The government attempted a series of reforms designed to improve TSOE performance, ${ }^{33}$ including delegating more production decisions down to the level of the enterprise, reducing the share of output that fell under the state plan-thus allowing a certain portion to be sold at market prices at the manager's discretion - and introducing a contracting system in which the TSOE was given fixed targets, with the benefits of overfulfillment to go to the managers (and possibly the workers).

These reforms had varying degrees of success, but further reforms were needed. Ultimately, the policy of corporatization was adopted as the foundation of further reforms, and the Company $\mathrm{Law}^{34}$ was passed in the service of those reforms. As a result, it bears their stamp; the need of nonstate actors for a convenient form in which to conduct business occupied a very low priority in the minds of state policymakers, and corporate governance has traditionally been concerned more with regulating and suppressing than with fostering and nurturing. ${ }^{35}$

${ }^{33}$ For an overview of these reforms, see generally Barry Naughton, Growing Out of the Plan: Chinese Economic Reform 1978-1993 (Cambridge Univ. Press 1995).

${ }^{34}$ China first passed a Company Law in 1993. See Zhongbua Renmin Gongheguo Gongsi Fa [Company Law of the People's Republic of China], adopted Dec. 29, 1993, effective July 1, 1994 (hereinafter 1993 Company Law]. The 1993 Company Law was substantially amended in 2005. See Zhonghua Renmin Gongheguo Gongsi Fa [Company Law of the People's Republic of China], amended Oct. 27, 2005, effective Jan. 1, 2006 [hereinafter 2005 Company Law].

${ }^{35}$ Indeed, it would be anomalous were it otherwise. There is a deep-rooted official suspicion of accumulations of wealth not controlled by the state or its officials, coupled with the suspicion of any organized activity not firmly under state leadership. A government that bans unauthorized fishing clubs and associations for the study of antique furniture and paper-cutting, see ZHONGHUA RENMIN Gongheguo Minzheng Bu Gonggao [Bulletin of the People’s Republic of China 
An important legacy of this transformation is that the administrative channels of control present in the TSOE have not disappeared, but often continue to function in the shadows, supplanting the formal channels envisaged in the Company Law. The board of directors may be bypassed entirely in matters such as appointment of the chief executive officer or other important decisions. Instead, the government agency that controlled the firm before its restructuring will issue instructions in much the same way after restructuring. ${ }^{36}$

Current policy respecting TSOEs is essentially to abolish the form by converting them into some form of company governed by the Company Law: (a) a joint stock company (JSC) (gufen youxian gongsi), the approximate equivalent of the large stock corporation in Western countries, (b) a limited liability company (LLC) (youxian zeren gongsi), intended for a much smaller and more closely knit group of investors, or (c) a wholly state-owned limited liability company (WSOLLC), a special type of LLC that may be wholly owned by a state agency. This process, which does not necessarily involve privatization - it all depends on who owns the shares in the converted company-is already well under way.

The theory driving the corporatization policy is the idea that state assets can be better managed through the use of a different organizational form. Another important consideration in adopting the corporate form, however, was that it made possible the raising of money in equity markets, and indeed it is this opening of ownership interests to the public that has made corporate governance more than simply a way of thinking about internal state asset management procedures.

A final point to note about the corporatization policy is to clarify what it is not: privatization or state withdrawal from the economy. The state remains firmly committed to retaining control over enterprises in several sectors: national security-related industries, natural monopolies, sectors providing important goods and services to the public, and important enterprises in pillar industries and the high-technology sector.

Indeed, part of enterprise reform involves a magnification of the scope of direct state control through leverage. ${ }^{37}$ In the traditional economic system, the state (through one or more of its agencies) was the sole owner of a TSOE and exercised full control over it. Corporatization, through the institution of divisible equity shares, allows non-state investors to contribute to the enterprise

Ministry of Civil AfFAirs], No. 41, June 6, 2003, available at http:/ / tinyurl.com/6dp7pu [hereinafter Proscription Notice], is unlikely to welcome the unbridled blossoming of organizations whose purpose is to make real money.

${ }^{36}$ This can happen because the directors understand that that is the way things are done in the company in question. If their signature is later needed on some ratifying document, it would be quixotic to refuse to provide it.

${ }^{37}$ See Chinese Communist Party Central Committee, Guanyu Guoyou Qiye Gaige he Fazhan Ruogan Zhongda Wenti de Jueding [Decision on Several Important Questions in the Reform and Development of StateOwned Enterprises], passed Sept. 22, 1999; Jiang Qiangui, Gongsi Zhili yu Guoyou Qiye Gaige [Corporate Governance and State-Owned Enterprise Reform], Zhongguo Zhengquan Bao [China Securities NEWs], June 12, 2001 (remarks of vice chairman of the State Economic and Trade Commission); Ngok Ma et al., Advance and Retreat: The New Two-Pronged Strategy of Enterprise Reform in China, 48 Problems of Post-Communism 52 (2001). 
without, while they remain in a minority, sharing in control. The state maintains the same level of control it had before, but now over a larger pool of assets. ${ }^{38}$

\section{Capital Structure}

Under both the original and the revised Company Law, JSCs may have only one class of shares: common. ${ }^{39}$ It is crucial to understand, however, that there are nevertheless several different types of common shares, distinguished by rules about their ownership and trading. ${ }^{40}$

One important distinction is that between circulating shares and non-circulating shares. Circulating shares are shares that may be traded freely and publicly on various stock markets. Noncirculating shares are, like circulating shares, common stock, but they are subject to severe trading restrictions. In particular, they are not tradeable on the markets. The category of non-circulating shares was created when SOEs began restructuring into JSCs and offering their stock to the public. It was felt necessary at the time to have an institutional guarantee of continued state domination of such companies in order to avoid the suspicion of creeping privatization. Therefore, the shares retained by the state in an IPO, as well as the shares owned by the state in JSCs that had not had an IPO, were generally designated "state shares" (guojia gu) and could be owned only by state organs.

Typically, restructuring SOEs were required to have about one third of their shares as state shares. Another third would go to the public. The rest was a second category of non-circulating shares called "legal person shares" (faren gu). These may be owned only by organizations with formal legal personality, such as companies. They would typically go to SOEs that contributed capital to the restructuring company before the IPO_-for example, holding companies, non-bank financial institutions, and SOEs with a non-state equity holder. These shares can also be held by government bureaux, leading to some confusion in the distinction between state and legal person shares. Although these shares cannot be traded on the market, they can be traded between legal persons with the agreement of the exchange where the company is listed. ${ }^{41}$

The existence of a large block of non-circulating shares came under increasing criticism over the years both within China and abroad for its distortionary effects, and after several false starts a scheme was finally devised in 2005 for bringing them on to the market. ${ }^{42}$ By the end of 2006, the

${ }^{38}$ As a former senior policymaker recently boasted, with an equity stake of a mere $6 \%$, the state controls the $94 \%$ of "social capital" in the Guangzhou Light Industrial Group, and the enterprise is classified as "state-controlled." See Zhang Jing \& Xu Shengru, 196 Jia Zhongyang Qiye Da Zhenghe: Yanchu Kaishi le [Big Reorganization of 196 Central Enterprises: The Performance Has Begun], 21 SHIJI JINGJI Baodao [21st Century Economic Report], July 14, 2003.

${ }^{39}$ See 1993 Company Law, supra note 34, art. 135 (stating that additional classes of shares may be provided for only through State Council rules); 2005 Company Law, supra note 34, art. 132 (same).

${ }^{40}$ For a fuller account of share types, see WALTER \& HowIE, supra note 32, at 71-87.

${ }^{41}$ See Stephen Green, Drafting the Securities Law: The Role of the National People's Congress in Creating China's New Market Economy 15 (Royal Institute of International Affairs, Mar. 2003).

${ }^{42}$ For accounts of the scheme, see Suet Lin Joyce Lee, From Non-Tradable to Tradable Shares: Split Share Structure Reform in China's Listed Companies, 8 J. Comp. L. STUd. 57 (2008); Wallace Wen-Yeu 
vast majority of listed companies had completed the process of formally reclassifying non-circulating shares as circulating, ${ }^{43}$ but a large quantity of reclassified shares are still subject to lock-ups and may not yet be freely sold. ${ }^{44}$

\section{Who Owns Them?}

Because of the rules regarding initial distribution of shares, until recently the typical shareholding pattern in listed companies was about 30\% for each of the state, legal persons, and domestic public shareholders (holders of circulating shares), with 10\% going to foreigners and employee shares. ${ }^{45}$ Although this rough average seems robust over several studies, one study finds that the standard deviation is large, showing that there are large variations in the formal ownership mix across firms.

Understanding the composition of the owners of circulating shares-in particular, the balance between individual and institutional shareholders-is difficult. But it is critical to understanding how capital markets might affect corporate governance.

The stereotype image of the Chinese stock market—one that I shall argue below is mistaken - is one dominated by small investors. Until the recent stock market boom, one read frequently of China having 70 million individual investors ${ }^{46}$ - about one in five urban residents between the ages of 15 and 64. This fanciful number, based on a confusion between the number of

Wang \& Jian-Lin Chen, Bargaining for Compensation in the Shadow of Regulatory Giving: The Case of Stock Trading Rights Reform in China, 20 Colum. J. Asian L. 298 (2006-07); Andrea Beltratti \& Bernardo Bortolotti, The Nontradable Share Reform in the Chinese Stock Market (November 2006), available at http://ssm.com/abstract=944412; Gan Peizhong \& Meng Gang, Lun Guquan Fenzhi Gaige Fang'an Zhong de Toupiao Biaojue Zhidu_Jian Tan Baohu Liutong Gu Xiao Gudong Quanyi de Zhidu Goujian [On the Voting System in the Plan for Reform of the Segregated Equity System-Also on the Construction of the System for Protecting the Rights and Interests of Small Circulating Shareholders] (2005) at http://article.chinalawinfo.com/article/user/article_display.asp?ArticleID=30456.

${ }^{43}$ See Guo Cheng, Liangyuan Yu \& Changwen Ke, Understanding the Chinese Stock Market, $18 \mathrm{~J}$. Corp. Accounting \& Fin. 13, 19 (Sept./Oct. 2007) (1,301 companies, with only 40 companies remaining).

${ }^{44}$ As of September 2007, the CSRC's web site showed the market capitalization of circulating shares to be just one third the value of total market capitalization (valuing all shares as circulating shares), indicating that it defines as non-circulating about two thirds of the outstanding shares of listed companies.

${ }^{45}$ This stylized fact was first established in Xiaonian Xu \& Yan Wang, Ownership Structure and Corporate Governance in Chinese Stock Companies, 10 CHIn ECON. REv. 75, 76 (1999); see also Ren Haichi, Ruhe Youbua Woguo Shangsi Gongsi Ziben Jiegou [How to Improve the Capital Structure of China's Listed Companies], Shanghai Jinrong Xueyuan Xuebao [J. Shanghai Inst. Fin.], No. 2, 2004, at 60,60 .

46 See, e.g., 7000 Wan Gumin Qunian Meihu Junping Kuisun 2045 Yuan $[70$ Million Stock Investors Lost 2045 Yuan Per Person on Average Last Year], Beijing Xiandai Shangbao [Beijing Modern Bus. NEWs], Jan. 5, 2005. 
stock accounts and the number of investors, was debunked years ago in both Chinese ${ }^{47}$ and English writings. Walter and Howie, on the basis of a variety of data, put the number of actual holders of shares at five to ten million, and estimate the number of active traders to be from 500,000 to two million. ${ }^{48}$ The stock market boom of 2007 brought many more investors into the market, ${ }^{49}$ leading to claims of as many as 150 million investors. ${ }^{50}$ Such claims are unfounded. Many investors hold duplicate accounts - one in Shanghai and one in Shenzhen - and some control many more than two. Remarkably, fully two thirds of existing stock accounts bold no stock at all-possibly being held in reserve for market manipulation. ${ }^{51}$

Individuals appear to dominate because individual stock accounts constitute well over 90 percent of all accounts and hold roughly 90 percent of circulating shares by value. ${ }^{52}$ But these numbers are misleading. Recent research suggests that as much as forty to fifty percent of the value of circulating shares is controlled by official and unofficial investment funds, often using (legally or illegally) individual accounts; ${ }^{53}$ when one then adds in the value of circulating shares controlled by other institutions, the amount in the hands of individuals appears to be far less. In sum, probably no more than five percent of China's households are individual investors active in the market, and they probably hold no more than thirty percent of market capitalization. By contrast, about twenty percent of United States households hold shares directly, to say nothing of those holding shares through mutual funds, pension funds, and the like. ${ }^{54}$

Overall and within the non-circulating share block, ownership concentration is high in Chinese listed companies. This is what one would expect in a country such as China with weak

\footnotetext{
${ }^{47}$ See Woguo Zhen Gumin Buguo Yiqian Wan [True Shareholders in China Not More than Ten Million], Tianjin Ribao [Tianjin Daily], Dec. 13, 2001, at 3.

48 See WALTER \& Howie, supra note 32, at 148.

${ }^{49}$ For example, in the eighteen months from mid-2004 to the end of 2006, the number of stock
} accounts rose from 71.5 million to 78.5 million. In the next six months, the number shot up to 107 million. See CSRC Web site, http://www.csrc.gov.cn. On a single day-May 28, 2007-investors opened 385,000 new accounts. See Geoff Dyer, Share Trading Accounts in China Hit 100M, FInANCIAL Times, May 29, 2007.

${ }^{50}$ See David Barboza, To See a Stock Market Bubble Bursting, Look at Shanghai, New YorK TimeS, Internet edition, April 2, 2008 (citing sources at JPMorgan); Shu-Ching Jean Chen, Poor, Greedy And Powering China's Stock Market Boom, ForBES, Jan. 16, 2008, available at http://tinyurl.com/59huuv (claiming 136 million investors).

${ }^{51}$ See Arthur Kroeber, China Stock Frenzy, Financial Times, July 2, 2007.

52 See GREEN, supra note 41, at 70.

${ }^{53}$ See id. at 70; Barry Naughton, The Politics of the Chinese Stock Market, ChInA LEAdERSHIP MOnitor, No. 3, 2002, available at http:/ /www.chinaleadershipmonitor.org.

${ }^{54}$ See GreEn, supra note 41, at 72-73. 
institutions for investor protection, ${ }^{55}$ but given the overwhelming role played by government policy over the years in preventing dispersed ownership, there may well be room for less concentrated ownership even without improvements in investor protection.

In particular, control by a single state shareholder is quite common in Chinese listed companies. A study of corporate governance conducted in 2002 by the CSRC and the State Economic and Trade Commission (SETC) found that of 1015 controlling shareholders in the 1175 listed companies studied, 77\% could be considered state organs (guojia xingzhi), while in 390 companies a single state shareholder held over half of the shares. ${ }^{56}$

This feature of listed company ownership structure-the concentration of controlling shareholdings in state agencies and holding companies-makes China an outlier among a number of countries,${ }^{57}$ and of course raises questions about the transplantability of corporate governance models from those countries.

\section{Institutions of Corporate Governance in China}

What, then, are the institutions of corporate governance, and how do they interact with particular types of norms? In this Part, I shall discuss a number of such institutions both generally and in their Chinese context.

To understand the challenges facing any corporate governance regime in China, it is important to understand something about the players, both human and institutional, who have a stake in policy or can influence it. Who is the intended decision-maker or norm enforcer, and is that person or institution better suited to the task than any alternative person or institution?

A common complaint among Chinese academics and lawyers, for example, is that the rules of the Company Law are too general and are not usable. Certainly this is true some of the time-how, for example, should one begin to interpret "relatively large in scale" in Article 52 of the old Company Law?" ${ }^{58}$ But sometimes the expectations of the critics seem unrealistic. No piece of legislation can spell everything out; the key is to have an alternative system available to supplement legislative gaps. Often the detailed standards they cite with approval come not from the legislation of other countries but from case law, or have been developed through case law. ${ }^{59}$

${ }^{55}$ See La Porta et al., supra note 25, at 14.

${ }^{56}$ The study is reported in Guojia Jing Mao Wei Fuzhuren Jiang Qiangui: Zuo Shangshi Gongsi Chengxin Fuze de Konggu Gudong [SETC Vice Chairman Jiang Qiangui: Be a Sincere and Responsible Listed Company Controlling Shareholder], JingJi Ribao [ECON. DAiLY], Jan. 30, 2003.

${ }^{57}$ See, for example, the table in Stoyan Tenev \& Chunlin Zhang, Corporate Governance And Enterprise Reform in China: Building the Institutions of Modern Markets 82 (World Bank and International Finance Corporation 2002).

${ }^{58}$ Or "relatively small in scale" in the corresponding article 52 in the new Company Law.

${ }^{59}$ See, e.g., Xu Yongqian \& Li Yulong, Gongsi Zhili yu Gudong Baohu [Corporate Governance and the Protection of Shareholders] 6 (Paper for 21 st Century Commercial Law Forum, Qinghua Univ., Nov. 18, 2001) (citing with approval tests developed in U.S. law such as "interest or expectancy," "line of business," and "fairness"). 
A further complaint is that even when the rules of the Company Law are clear, regulated parties do not obey them, or else the forms provided by the law, such as the board of supervisors, remain decoratively on the shelf but do not function as the drafters intended. Commentators tend to blame the actors for acting in ways that do not conform to the law's idealized structure. But the real fault lies in the law's failure to provide an enforcement mechanism, in particular one that can be activated by those who are hurt by non-compliance. It is pointless from a policymaking perspective simply to blame the non-compliant, since the only policy consequence of blame is the hope that they will have a change of heart and do better in the future.

This Part attempts to enrich our understanding of the institutional context for corporate governance in China by looking at particular mechanisms by which the rules and standards might be made meaningful. ${ }^{60}$ It concludes with a detailed examination of both the CSRC and the court system and assesses their potential for playing an important role.

\section{A. The Role of Stock Markets and External Debt in Corporate Finance and Corporate Governance}

Several institutions exist that align the interests of managers and shareholders. ${ }^{61}$ If a corporate governance scheme does not rely on legal sanctions or the good conscience of parties, it can use markets of various kinds-product markets, capital markets, and labor markets - to pressure parties to act as desired. These markets impose some degree of discipline on management, but the discipline is often loose, not tight. It may take time for selection pressures to act on firms operating sub-optimally. ${ }^{62}$

${ }^{60}$ For reasons of space, I have omitted discussion of a few potentially important institutions because at present there is less to say about them than about others. The threat of a hostile takeover can play a role in disciplining management and reducing agency costs, but hostile takeover attempts are extremely rare in China. An active financial press can also play an important role in corporate governance by providing information to the investing public and by posing the threat of a public shaming to dishonest or incompetent managers. And intra-corporate monitoring by independent directors or (in China) the board of supervisors (jianshi bui) can at least in theory play some role; I have discussed that extensively in another article. See Donald C. Clarke, The Independent Director in Chinese Corporate Governance, 36 DEL. J. CORP. L.125 (2006).

${ }^{61}$ See Roe, supra note 16, from the list in which several of the institutions examined here are taken.

${ }^{62}$ It is a standard claim of the law-and-economics literature that competitive pressures, where they exist, drive out inefficient structures through a survival-of-the-fittest selection process. That this may be true in long-run equilibrium does not, however, make it true that at any given moment no inefficient structures can be observed. It takes time. Miwa and Ramseyer, for example, while sometimes acknowledging that competitive pressures "drive firms toward" a firm-specific optimum number of outside directors, elsewhere go much further and assert in effect that all firms are always already there. See Yoshiro Miwa \& J. Mark Ramseyer, Who Appoints Them? What Do They Do? Evidence on Outside Directors from Japan (Harvard Univ., John M. Olin Center for Law, Economics and Business, Discussion Paper No. 374, July 2002), available at http://papers.ssrn.com/abstract_id=326460 (analogizing a sub-optimal number of outside directors to $\$ 20$ bills lying on the sidewalk in order to conclude that all firms in their survey must already have the optimal number). This vastly overestimates the flexibility of human institutions. See also Rational Choice 26 (Jon Elster ed., N.Y. Univ. Press 1986) (questioning the applicability of the 
When economic reform began in China in 1979, markets did not discipline managers because little economic activity of importance took place on a market basis. Over time, competition—especially in product markets—has increased. Nevertheless, a number of companies remain in protected markets; this gives their management a degree of slack.

Two important markets are those for external debt and equity financing. To understand the Chinese corporate governance environment, then, we must understand both.

\section{Historical Background}

In the pre-reform era it made little sense to talk about equity and debt financing at all, let alone equity and debt markets. The TSOE of the pre-reform era received all its funding from government bureaux of various kinds. There was no financial market in the sense of firms seeking financing by offering competitive terms, or suppliers of funds offering financing in the same way. There were banks that performed an intermediation function by collecting the funds of individual depositors, to be sure, but they allocated them to firms according to government direction, acting essentially as cashiers. ${ }^{63}$

If the firm received money directly from its government administrative superior, the transfer would be characterized as a grant; if the money came from a bank, it would be called a loan. But even if the funds came with the label of "loan", firms operated under a soft budget constraint ${ }^{64}$ and were under no particular pressure to repay. While firms still competed for money, they did so on a bureaucratic, not a market basis.

This system began to undergo reform in the 1980s, when four major state-owned banks ${ }^{65}$ were established to handle conventional banking. In the 1990s, so-called "policy banks" were created to handle non-market-based lending, while the other banks-including newly authorized

biological analogy to economic activity on the grounds that the economic environment changes rapidly relative to the speed with which inefficient firms are eliminated from competition, and that therefore at any given time we are likely to observe efficient and inefficient firms coexisting); Mark Granovetter, Economic Action and Social Structure: The Problem of Embeddedness, 91 AM. J. Soc. 481, 503 (1985) ("The operation of alleged selection pressures is . . neither an object of study nor even a falsifiable proposition but rather an article of faith.”).

${ }^{63}$ On the pre-reform era banking system, see generally NiCHOLAs R. LARDY, CHINA's Unfinished Economic Revolution (The Brookings Inst. 1998).

${ }^{64}$ The essence of the soft budget constraint is the notion that the difference between proceeds of production and costs of production is not a matter of life and death for the firm, and that this difference therefore does not act as an effective constraint on firm behavior. See JANOs KornAI, Economics of Shortage 302-14 (1980); Janos Kornai, The Soft Budget Constraint, 39 Kyklos 3 (1986).

${ }^{65}$ The Bank of China, the Industrial and Commercial Bank of China, the Construction Bank of China, and the Agricultural Bank of China.

${ }^{66}$ The Agricultural Development Bank of China, the China Development Bank, and the Export-Import Bank of China. 
“joint stock" banks ${ }^{67}$ owned by local governments together with other institutional and occasionally private investors-were supposed to make loans based on commercial criteria. While these other banks may be more profit-oriented than the Big Four, they are still subject to significant political influence in their functioning (they are typically owned in part by local governments) and have not been able to escape the obligation to make "policy loans". ${ }^{68}$ Partly for this reason, non-performing loans became a major burden on the banking sector in the 1990s, and by the late 1990s, the system was insolvent. ${ }^{69}$

Although the stock markets had been in existence since 1990, it was in 1996 that the government, looking for an alternative to bank lending, turned to them as a way of providing a new source of financing for the troubled state sector. This marked the beginning of unequivocal state support for stock markets. It also solidified some key features of the Chinese stock markets: first, that their primary role has been not to allocate capital to the most efficient enterprises, but to raise money for restructuring SOEs, and second, that the state has been both regulator and cheerleader, with the specific mission of keeping stock prices up in order to support the financing of SOEs. ${ }^{70}$

\section{The Stock Market in Recent Years}

\section{a. How Important Is It?}

Given the support China's stock markets have received from the state, much writing on them unsurprisingly assumes that they are critical to the Chinese economy. At least until recently, this assumption has been questionable.

China's two stock markets both began operations in late $1990 .^{71}$ By the end of 2005, they had grown to the point of having 1,381 listed companies with a circulating share capitalization of 1.06 trillion yuan (approximately $\$ 132$ billion), ${ }^{72}$ or six percent of gross domestic product in that year. This put China around twentieth in the world in terms of market capitalization. Looking at market capitalization as a percentage of GDP in 2006, the United States showed 148 percent, while Hong

${ }^{67}$ Such banks include the Bank of Communications, the Shenzhen Development Bank, China Everbright Bank, and the China Merchants Bank.

${ }^{68}$ See Stephen Green, China’s Stockmarket: Eight Myths and Some Reasons to Be Optimistic 22 (The China Project, Royal Institute of International Affairs and Cambridge University, Feb. 2003). During the Asian financial crisis, for example, the government ordered the banks to lend heavily in order to stimulate the economy.

${ }^{69}$ See GREEN, supra note 68, at 22.

${ }^{70}$ See Chao Gupiao, Panic Attack, China Economic Quarterly, June 2008, at 16; Yelin Zhang, The Roles of Corporatization and Stock Market Listing in Reforming China's State Industry, 32 WorLD Development 2031, 2044 (2004); Sebastian Heilmann, The Chinese Stock Market: Pitfalls of a Policy-Driven Market, China AnAlysis, No. 15 (Sept. 2002), available at http:/ /www.chinapolitik.de.

${ }^{71}$ Although the Shenzhen Stock Exchange was not formally established until 1991, some trading took place in the previous year..

${ }^{72}$ See CSRC Web site, http://www.csrc.gov.cn. 
Kong showed 904 percent. Other transition economies such as the Czech Republic, Poland, and Russia show 34 percent, 44 percent, and 107 percent respectively. ${ }^{73}$ In short, the stock market is not large by most measures.

Why, then, were there at the same time widespread claims that China's market capitalization was about $\$ 500$ billion, ${ }^{74}$ ranking China ahead of Hong Kong and behind only Japan in Asia? The answer is that such claims unrealistically valued non-circulating shares as if they were circulating shares. All the available empirical evidence shows that non-circulating shares-historically as much as two thirds of capital stock-sell at a large discount to circulating shares, sometimes by as much as 90 percent. $^{75}$ An economically realistic valuation would therefore be much lower.

In the spring of 2006, however, the market capitalization of Chinese listed companies, however measured, began to rise dramatically. From the end of March 2006 to the end of May 2007, the market capitalization with all shares valued (unrealistically) equally rose from 3.54 trillion yuan (US $\$ 468$ billion) to 17.8 trillion yuan (US\$2.36 trillion). The market capitalization of circulating shares rose from 1.23 trillion yuan (US $\$ 164$ billion) to 5.94 trillion yuan (US $\$ 786$ billion) in the same period. ${ }^{76}$ This certainly makes Chinese stock markets more important than previously. At the same time, however, the market surge evident in mid-2007 now stands revealed as a bubble.. ${ }^{77}$ By some measures, Chinese market capitalization exceeded Japan's as of late August 2007, a conclusion that

${ }^{73}$ See World Bank, World Development Indicators (various years), available at http://go.worldbank.org/XML5QSOCR0. The absolute numbers for market capitalization, sourced from the World Development Indicators, are available in convenient comparative form at the Nationmaster.com Web site: http://tinyurl.com/5lm45h.

${ }^{74}$ See, e.g., Chong-En Bai et al., Corporate Governance and Market Valuation in China (William Davidson Institute, Working Paper No. 564, 2003), available at http://ssrn.com/abstract=393440; China to Complete State-Share Reforms This Year, CHInA Daily, Internet ed., Apr. 24, 2006 (Agence FrancePresse report); Written Statement of the Securities Industry Association, in UnITED STATES-ChINA Economic Relations and China's Role in the Global Economy: Hearings Before the House Comm. On Ways And MeAns, $108^{\text {th }}$ Cong. (2003), available at http://www.sia.com/testimony/2003/siatestimony10-03.html.

75 See Zhiwu Chen \& Xiong Peng, The Illiquidity Discount in China (International Center for Financial Research, Yale Univ., 2002) (finding that non-circulating shares on average have a $70 \%-80 \%$ illiquidity discount when traded on informal markets); WALTER \& HOWIE, supra note 32, at 186. For more extended discussions of how to value listed companies, see GrEEN, supra note 41, at 6; WALTER \& HOWIE, supra note 32, at 188-89.

${ }^{76}$ See CSRC Web site, at http://www.csrc.gov.cn. Another useful Web site for Chinese stock market data is at http://www.hkex.com.hk/csm/highlight.asp?LangCode=en.

77 As of July 24, 2008, the Shanghai Stock Exchange index was at 2910; in mid-October 2007, it peaked at over 6000. See Yahu Caijing Pindao [Yahoo Finance and Economics Channel], available at http:// finance.cn.yahoo.com/; see also Barboza, supra note 50. 
seems hard to justify. ${ }^{78}$ As of the end of June 2008, China's circulating share capitalization was $\$ 868$ billion (about $9.7 \%$ of GDP), while its total capitalization, valuing non-circulating shares as if they were circulating shares, was $\$ 2.6$ trillion (about $29 \%$ of GDP).

In terms of funds raised for investment, the stock markets also are not important. In 2002, the stock market provided only $\$ 8.9$ billion of corporate finance, while bank loans provided $\$ 217.7$ billion. $^{79}$ But while bank loans account for the lion's share of external financing, it is important to realize that external financing as a whole is much less important than one might think. In 2005, about $40 \%$ of fixed asset investment was funded by enterprise "self-owned" funds (probably retained earnings and possibly including depreciation and amortization amounts), compared with a mere $0.05 \%$ funded by equity issues. ${ }^{80}$ On the whole, then, "[b]oth the scale and relative importance (compared with other channels of financing) of China's external markets are not significant."

\section{b. Characteristics of Investors}

Understanding who the investors are and how they behave has critical implications for corporate governance. First, it helps us understand whether equity markets can in fact serve a disciplining function. Do they respond to failures of corporate governance? Second, it helps us to assess the necessity and urgency of measures to help the small investor who, in the popular image of the stock market, is getting roughed up by the big boys. If small investors threw up their hands and left, would it matter?

Current research presents a mixed picture. The picture of the average investor as a naive retiree staking his retirement savings is false. ${ }^{82}$ Only 17 percent are over 55, and they tend to play

${ }^{78}$ See Geoff Dyer, Chinese Stock Market Bigger Than Japan's, Financial Times, Aug. 29, 2007. In the words of Fraser Howie, a long-time observer of the Chinese market quoted in the story, "All reality has been suspended in China."

${ }^{79}$ See Stephen Green, Better Than a Casino: Some Good News from the Frontline of China's Capital Market Reforms (Royal Institute of International Affairs, Asia Programme Working Paper No. 6, 2003) (citing sources); see also GREEN, supra note 68, at 29 (table showing comparative data for 1993 through 2002); Franklin Allen, Jun Qian \& Meijun Qian, Law, Finance, and Economic Growth in China (Wharton Financial Institutions Center Working Papers Series, No. 02-44, Dec. 23, 2002) 17-19, available at fic.wharton.upenn.edu/fic/papers/02/0244.pdf.

${ }^{80}$ See CEIC Data, Premium China Database, available at http://www.ceicdata.com/china.htm. Substantial amounts of investment also come from categories of unclear significance labeled "other". But the insignificance of the equity amounts is clear.

${ }^{81}$ Franklin Allen, Jun Qian \& Meijun Qian, Law, Finance, and Economic Growth in China, 77 J. FIN. ECON. 57, 73 (2005).

${ }^{82}$ Consider, for example, the case of Si Dansu, a retiree quoted in a recent news article as saying that she had invested all her her savings ten years ago and lost them in the recent downturn in the stock market. See Barboza, supra note 50. This tale might be true, but certainly it is implausible on its face, because ten years ago the Shanghai Stock Exchange index was at about 1500 to 2000, whereas when the article about her was written, the index was at about 3400 . 
the market as a pastime, like bingo. ${ }^{83}$ Institutional investors, not fickle individuals, play the dominant role in market movements. ${ }^{84}$ And the trading strategy they adopt is largely speculative: the average holding period in China is about one to two months, compared with 18 months in the United States. ${ }^{85}$ In addition, China's stock markets have a high degree of synchronicity: one study found that 80 percent of the stocks listed on the two exchanges moved in the same direction in a given week. ${ }^{86}$ This degree of synchronicity is the second highest among stock markets in forty countries; it suggests that stock prices move in response to information about the market in general, not about specific firms. ${ }^{87}$ In other words, Chinese investors rationally worry more about the latest twists and turns in government policy or other market-level rumors than about corporate results. At the same time, however, a number of studies have found that Chinese investors do respond rationally to corporate-level events. ${ }^{88}$

Inconsistent as some of empirical findings are, it is nevertheless possible to draw a few tentative conclusions from existing research. First, the picture of the Chinese stock market as solely speculative is probably overstated. Investors are more concerned with fundamentals and governance than observers give them credit for. Thus, good governance will ultimately be rewarded.

Second, while a great deal of speculation does take place on the market, it is driven by institutional investors, not individuals. Therefore, current government policy-which blames individuals for speculation and attempts to curb it by encouraging institutional investors who will, it is assumed, take a longer-term perspective-is unlikely to be successful.

${ }^{83}$ For a full analysis of the investor community, see GREEN, supra note 41, ch. 4 and WALTER \& HowIE, supra note 32, ch. 7.

${ }^{84}$ On institutional investors, see Hong KOng STOCK Exchange, Institutional Investors IN MAINLAND CHINA (Jan. 2004), at http://www.hkex.com.hk/research/rpapers/IIMC.pdf.

${ }^{85}$ See Xu \& Wang, supra note 45, at 85. A more recent study finds a turnover velocity of $509 \%$ in 2000. See Eric C. Chang \& Sonia M.L. Wong, Political Control and Performance in China's Listed Firms 25 (March 2003), available at http://www.hiebs.hku.hk/working_papers.asp?ID=89. See also Bei Hu, Exposure to Stocks Unhealthy; Trading Mostly Speculative, S. China Morning Post, Apr. 16, 2002, at B4.

${ }^{86}$ See Randall Morck et al., The Information Content of Stock Market: Why Do Emerging Markets Have Synchronous Stock Price Movement?, 58 J. FIn. ECON. 215 (2000). For further studies confirming the high synchronicity of Chinese stock markets, see Art Durnev, Kan Li, Randall Morck \& Bernard Yin Yeung, Capital Markets and Capital Allocation: Implications for Economies in Transition, 12 ECON. OF Transition 593 (2004) and Merritt Fox, Artyom Durnev, Randall Morck \& Bernard Yeung, Law, Share Price Accuracy, and Economic Performance: The New Evidence, 102 Mich. L. REv. 331 (2003).

${ }^{87}$ See Chang \& Wong, supra note 85 , at 25.

${ }^{88}$ See, e.g., Bai et al., supra note 74, at 22 (" $[\mathrm{B}]$ etter governed companies in China are highly regarded in China by investors who are willing to pay a premium for high governance standard." ); Charles J.P. Chen, Shimin Chen \& Xijia Su, Is Accounting Information Value-relevant in the Emerging Chinese Stock Market?, 10 J. InT'L Accounting, Auditing \& TAxATIOn 1 (2001) (investors react rationally to accounting numbers). 
Third, policymakers in the field of corporate governance should not worry so much about the small investor. ${ }^{89}$ He is not a major source of funds, and in any case can be no more than a price taker. Contrary to government fears, a market downswing will not bring 70 or 150 million angry citizens into the street protesting the loss of their life savings. It would, of course, create massive discontent among a small elite of the wealthy and powerful, which may be an equally good explanation of government fear of a falling market. But it is not the same thing.

3. $\underline{\text { Banks }}$

Capital structure has implications for oversight: when a corporation has dispersed ownership and low leverage, managers have a great deal of slack. Conversely, high debt levels lead to close monitoring by creditors. To the extent that creditors' interests are congruent with those of shareholders — and they often are-shareholders can free-ride on creditor monitoring.

In many countries, banks play an important role in corporate governance. ${ }^{90}$ Unlike small shareholders, banks have both the ability and the incentive to monitor the financial health of their debtors, and may impose loan covenants requiring their consent for certain corporate actions. Indeed, academic research suggests that investment financed with bank debt tends to be more efficient than investment financed with retained earnings, probably because the former must be justified to a third party, whereas management's use of retained earnings is subject to no such oversight. $^{91}$

Banks may also be sufficiently dubious of a prospective borrower's financial health to refuse to lend at all, thus hastening the departure of a poorly run or otherwise inefficient company from the economy. And they may themselves be major shareholders, as in Germany or Japan, although not in the United States. ${ }^{92}$

${ }^{89}$ This is the advice for developing and transition economies generally of Erik Berglö \& Ernst-Ludwig von Thadden, The Changing Corporate Governance Paradigm: Implications for Transition and Developing Countries 24-25 (June 1999), available at http:/ / ssrn.com/abstract=183708.

${ }^{90}$ See generally Cheryl Gray, Creditors' Crucial Role in Corporate Governance, 34 FINANCE AND Development 29 (1997). Corporate governance literature typically distinguishes between two models: one reliant on equity finance and capital markets, and one reliant on debt finance with banks as major shareholders and creditors. See, e.g., Mark Roe, Some Differences in Corporate Structure in Germany, Japan, and the United States, 102 Yale L.J. 1927 (1993), Masahiko Aoki, Controlling Insider Control: Issues of Corporate Governance in Transition Economies, in CORPORATE GOVERNANCE IN Transitional Economies 3 (M. Aoki \& H.-K. Kim ed., 1995); Erik Berglöf, Corporate Governance in Transition Economies: The Theory and Its Policy Implications, in CORPORATE GOVERNANCE IN Transitional ECONOMIES 59.

${ }^{91}$ See Michael C. Jensen, Agency Cost Of Free Cash Flow, Corporate Finance, and Takeovers, 76 Am. Econ. Rev. 323 (1986); see generally Lihui Tian \& Saul Estrin. Debt Financing, Soft Budget Constraints, and Government Ownership: Evidence from China, 15 ECONOMICS OF TRANSITION 461, 462-63 (2007) (reviewing relevant literature).

92 See generally Mark J. Roe, Strong Managers, Weak Owners: The Political Roots of American Corporate Finance (1994). 
Chinese banks, however, have historically had neither the capacity nor the incentive to play this monitoring role. As discussed above, the traditional role of banks was that of cashier for the state. Even after the reforms of the 1980s, lending decisions were often based on political criteria and the perceived needs of SOE borrowers, not on the prospect of the loan being repaid from the proceeds of whatever project it was used to fund. ${ }^{93}$

Bankers thus did not have the tools to understand whether a loan was being put to good use or not; that was not a question with which they were intended to concern themselves, and the accounting system at the time would not have provided an answer. ${ }^{94}$ They were simply to supply the money when ordered to do so. Nor did they need to worry about defaults; profit was simply not the objective and played no significant part in the evaluation of bank executives.

Moreover, once profits did become important, it was book profits as reported to administrative superiors that mattered both to the bankers and to their superiors; thus, banks were forbidden to write off-i.e., declare a loss on-more than a portion of their non-performing loans. Attempting to put a defaulting debtor into bankruptcy would also have had the effect of forcing the bank to close the books on a bad loan, instead of keeping it on the asset side by lending the borrower enough money to make interest payments.

The result of all this is that banks have lacked what might be called a culture of monitoring. ${ }^{95}$ The very lack of a monitoring culture in banks has shaped corporate law significantly, as the state has tried to do through corporate law what the banks seem incapable of doing for themselves:

${ }^{93}$ See Su Dongwei, Corporate Finance and State Enterprise Reform in China 6 (Nov. 18, 2000), available at http://ssrn.com/abstract=250802 ("If [a] political favor is deemed appropriate, subsidized loans, rescheduling of overdue debt or even outright transfer of funds can be arranged with SOEs [stateowned enterprises.]"). See also Part IV.A supra.

${ }^{94}$ The Chinese accounting system in the pre-reform era was typical for a planned economy: it was about matching sources to uses to monitor the spending of funds as the funder intended. It was not about matching revenues to expenditures to ensure that investments were profitable. See generally Allen Huang \& Ronald Ma, Accounting in China in Transition: 1949-2000, at 25-28 (2001). And the design of current accounting rules often owes as much to the need to ensure tax revenues as to the need to match revenues with expenditures. See Charles J.P. Chen, Ferdinand A. Gui \& Xijia Su, A Comparison of Reported Earnings Under Chinese GAAP vs. LAS: Evidence from the Shanghai Stock Exchange, 13 Accounting Horizons 91, 102 (1999) (citing CHI-WAN YANG \& Jiliang YAng, Handbook of Chinese Accounting (1999)).

${ }^{9}$ See Clement Kong Wing Chow \& Michael Ka Yiu Fung, Ownership Structure, Lending Bias, and Liquidity Constraints: Evidence from Shanghai's Manufacturing Sector, 26 J. ComP. ECON. 301, 303 (1998); Jenny J. Tian \& Chung-Ming Lau, Board Composition, Leadership Structure and Performance in Chinese Shareholding Companies, 18 Asia PACIFIC J. Of Mgmt. 245, 249 (2001). 
protecting their interests as creditors. ${ }^{96}$ In other words, far from enlisting the help of banks in monitoring corporations, China's corporate law sees them as passive victims that need protection.

Recent scholarship suggests that the monitoring value-added of banks in Germany and Japan is much less than was supposed during the eighties, when German and Japan corporate governance models were in vogue. ${ }^{97}$ If German and Japanese banks find it difficult to monitor effectively, it is easy to see that it is unrealistic to expect Chinese banks to manage. And because banks are often still required to lend for political reasons, the result is that corporate management has been subject to the discipline neither of the credit market when seeking a loan nor of lender monitoring after obtaining it.

Although banks do not seem to monitor well, it is still possible that debt financing could improve corporate governance by reducing free cash flows subject to management's discretionary control. ${ }^{98}$ Here recent research points in two directions: as in many other studies of corporate governance, ownership seems to matter. Listed companies controlled by a government shareholder actually display increased managerial agency costs (in the form of managerial perquisites, overinvestment, and corporate expenses) as leverage increases, whereas companies controlled by a commercial shareholder typically do not, or display reduced agency costs. ${ }^{99}$ It may be, therefore, that as shareholding in Chinese companies progressively shifts to non-government bodies, debt financing can be expected to play more of a role than it does today.

\section{B. Ownership Structure}

Large shareholders can often be reasonably effective in monitoring corporate managers; if they do not abuse their control rights, their efforts redound to the benefit of small shareholders as well. Many Chinese commentators, however, bemoan China's concentrated ownership structure as almost perverse and unnatural, and see the widely dispersed shareholding on the American model as

${ }^{96}$ Of course, every mature legal system provides a range of protection for corporate creditors; in the United States, such protection is accomplished largely through state law restrictions on corporate distributions and state and federal rules on fraudulent transfers. In China, however, corporate law protection is viewed as necessary to save creditors from their own misguided lending decisions-and such decisions can be very misguided indeed. Consider, for example, the case of the man who received a bank loan of 3.4 million yuan for his shell company that had no assets. Had the bank done any due diligence - simply to the extent of visiting corporate headquarters - it would have discovered that there was an overgrown field with a few small buildings at the company's address. See Wu Jianzhong, Yiqi Xubao Zhuce Ziben, Daikuan Zhapian An de Zhenpo yu Bianxi [The Breaking and Analysis of a Case of False Reporting of Registered Capital and Fraudulent Borrowing], ZHEJIANG GONGAN Gaodeng Zhuanke Xuexiao Xuebao [Journal of the Zhejiang Public Security College], No. 4, 2001, at 77-79.

${ }^{97}$ On the softness of German and Japanese bank monitoring, see Shleifer \& Vishny, supra note 15, at 773, and the sources cited in La Porta et al., supra note 25, at 17-18.

${ }^{98}$ See the sources cited in Tian \& Estrin, supra note 91, at 462-63.

99 See Tian \& Estrin, supra note 91. 
the ideal ownership structure. ${ }^{100}$ Yet the American model is the exception, not the rule, ${ }^{101}$ and in China's circumstances it is far from clear that dispersed ownership would be a good thing in any case. As the shareholder's ability to exploit the minority increases, so in tandem does its ability to monitor management to the benefit of all. Which effect will dominate cannot be known a priori.

Several studies of Chinese listed companies have found that in general, performance is positively correlated with concentrated ownership, ${ }^{102}$ at least to a point, and negatively correlated with dispersed ownership. ${ }^{103}$ The explanation typically offered is that large shareholders reduce the free rider problem of small, dispersed shareholders and are thus able to monitor management more effectively. In addition, dispersed ownership is especially costly in a society without the institutions that give the minority what little power and influence it might have, such as a well functioning legal system and an active financial information industry.

While finding that concentrated ownership is generally a good thing among Chinese listed companies, the same studies also find that performance is negatively related to the proportion of state shares and positively related to the proportion of legal person shares in the total capital stock. ${ }^{104}$ Thus, it is not simply any large shareholder that will do. The large shareholder must be an

${ }^{100}$ See, e.g., Ma Gengxin, Wanshan Woguo Shangshi Gongsi Duli Dongshi Zhidu Jianshe de Sikao [Some Thoughts on Perfecting the Construction of the Independent Director System in China's Listed Companies], 20 Zheng-Fa Luntan [Political-Legal Forum], No. 6, 2002, at 61, 62.

101 See Berglöf \& von Thadden, supra note 89, at 4 (observing that the widely held firm is rare in most countries, including transition economies).

102 "Concentrated ownership" must be understood here to mean concentrated ownership by state agencies or legal persons because concentrated ownership by individuals is virtually unknown.

103 See, e.g., Lü Hui \& Wu Xingming, Shangshi Gongsi Guquan Jiegou yu Gongsi Zhili [The Stock Ownership Structure and Corporate Governance of Listed Companies], Jingui Tizhi Gaige [Reform of THE ECONOMiC System], No. 4, 2004, at 88, 89-90 (reviewing various studies); Yu Xiaoming, Zhongguo Shangshi Gongsi de Guquan Jiegou yu Gongsi Jixiao [The Shareholding Structure of Chinese Listed Companies and Corporate Results], Shijie Jingui [World Economy], No. 9, 2003, at 50 (finding the best results when the largest shareholder holds between $20 \%$ and $50 \%$, and the worst results when holdings exceed 50\%); Jian Chen, Ownership Structure as Corporate Governance Mechanism: Evidence from Chinese Listed Companies, 34 Economics of Planning 53, 69 (2001); Daqing Qi et al., Shareholding Structure and Corporate Performance of Partially Privatized Firms: Evidence from Listed Chinese Companies, 8 PACIFICBASIN Fin. J. 587, 594 (2000); Sun Yongxiang \& Huang Zuhui, Shangshi Gongsi de Guquan Jiegou yu Jixiao [Shareholding Structure and Performance in Listed Companies], JingJI YANJIU [ECON. ReSEARCH], No. 12, 1999, at 23-30; Xu \& Wang, supra note 45, at 86-87.

104 See, e.g., Chen, supra note 103, at 68; Qi et al., supra note 103, at 604-05; Xu Xiaonian, Gongsi Zhili Jiegou: Zhongguo de Shijian yu Meiguo de Jingyan [The Structure of Corporate Governance: China's Practice and America's Experience] (Zhongguo Renmin Daxue Chubanshe 2000); Xu \& Wang, supra note 45, at 88; Lin Ling \& Dong Hong, Faren Zhili Jiegou yu Jingying Jixiao: Lai Zi Gao Keji Shangshi Gongsi de Shizheng Fenxi [Legal Person Governance Structure and Operational Results: An Empirical Analysis of High Technology Listed Companies], in Guo Feng \& Wang Jian, Gongsi Fa Xiugai Zongheng Tan [An AllAround Discussion of Reform of the Company Law] 204 (Falü Chubanshe 2000). 
institutional shareholder that is separate enough from the state so as not to be counted as a holder of state shares.

Research on U.S. firms suggests that the relationship between firm performance and ownership concentration is an inverted V: as concentration rises, performance rises at first, but then declines as concentration rises still further. ${ }^{105}$ The explanation, according to Shleifer and Vishny, is that "as ownership gets beyond a certain point, the large owners gain nearly full control and are wealthy enough to prefer to use firms to generate private benefits of control that are not shared by minority shareholders." 106

Yet the opposite pattern, if anything, has been observed in Chinese firms: one study found that performance, as measured by the ratio of market value to book value, followed a U-shaped curve as ownership concentration by legal person shareholders increased. ${ }^{107}$ Indeed, the same pattern was observed with respect to state shareholding. ${ }^{108}$ Another study found that performance peaked when the largest shareholder held $30 \%$ to $50 \%$ of the stock, and was worst when no shareholder held more than $30 \%{ }^{109}$

The standard explanation is that individual investors at first fear expropriation by such shareholders - that they will use their influence to expropriate-but believe that as their stake rises, the interests of the legal person shareholders will become more congruent with theirs. In other words, a controlling shareholder's ability to expropriate remains constant whether it owns $51 \%$ or $91 \%$, but its incentive to do so declines as its financial interest in the corporation increases.

This explanation has no less surface plausibility than the one offered by Shleifer and Vishny for the opposite effect. What this suggests is not that the explanations are too glib, but that the institutional differences between China and the United States are profound and lessons learned in one country may not be readily applicable to the other. Until further research is done, perhaps the most that can be safely said is that concentrated ownership by non-state shareholders is probably by and large a good thing that should not be discouraged by the law ${ }^{110}$ — there is some evidence that it is

105 See, e.g., John McConnell \& Henri Servaes, Additional Evidence on Equity Ownership and Corporate Value, 27 J. FIn. ECON. 595 (1990); Karen Wruck, Equity Ownership Concentration and Firm V alue, 23 J. FIn. ECON. 3 (1989). But see Harold Demsetz \& Kenneth Lehn, The Structure of Corporate Ownership: Causes and Consequences, 93 J. POL. ECON. 1155 (1985) (finding no significant correlation between ownership concentration and profit rates for 511 large corporations).

${ }^{106}$ Shleifer \& Vishny, supra note 15 , at 759.

107 See Xu \& Wang, supra note 45, at 91.

108 See George Lihui Tian, Government Shareholding and the Value of China's Modern Firms (University of Michigan William Davidson Institute Working Paper No. 395, April 2001).

109 See Lin \& Dong, supra note 104, at 205.

110 See Colin Lixin Xu, Tian Zhu \& Yi-Min Lin, Politician Control, Agency Problems and Ownership Reform: Evidence from China, 13 ECONOMICS OF TRANSITION 1 (2005) (finding that private ownership per se was insufficient to reduce agency costs, that concentrated private ownership was required, and that dispersed private ownership led to worse performance in Chinese companies). 
valued by the market ${ }^{111}$ —and that public shareholders are probably capable of taking the possibility of dominant-shareholder expropriation into account.

\section{Gatekeepers: Lawyers and Accountants}

Persons and institutions involved in information distribution and gatekeeping-including lawyers, accountants, securities analysts, underwriters, and the financial press-play an important role in corporate governance in many jurisdictions. The theory is that because they are repeat players whose income depends on reputation, the gains from maintaining that reputation will outweigh the gains from defecting and cooperating in fraud and mismanagement. Corporate insiders, it is thought, have the opposite set of incentives. ${ }^{112}$

To perform their function, all of these must of course be appropriately motivated. If lawyers and accountants bear no responsibility for their opinions, one cannot expect them to press their corporate clients to correct a state of affairs that damages shareholders. Similarly, one cannot expect much from the financial press if the rewards for providing accurate information are less than the rewards for not doing so.

Neither the legal nor the accounting profession in China is yet well equipped to play an effective gatekeeper role. The SEC has been able to delegate much of its supervisory burden to both professions in the United States because they are capable of handling the task. By contrast, China's lawyers are few in number and, like its accountants, not trained to handle complex financial matters. ${ }^{113}$ The law schools do not teach such topics, and the modern legal profession has not yet accumulated enough experience to enable juniors to learn from seniors on the job.

The position of the accounting profession is even worse. ${ }^{114}$ China has few qualified accountants. ${ }^{115}$ A 2001 study of 32 randomly selected audit reports found "gravely inaccurate

111 See Qi et al., supra note 103, at 609; Xu \& Wang, supra note 45, at 95. A problem with both of these studies is that they appear to assume that a given proportion of legal person shareholding is more concentrated than the same proportion of individual shareholding. This is probably true as an empirical matter, but it is not a necessary characteristic of legal person ownership.

112 See Ronald J. Gilson \& Reinier H. Kraakman, The Mechanisms of Market Efficiency, 70 VA. L. REV. 549, 595-607 (1984). But see Coffee, supra note 5 (arguing that reputation is not as effective a policing mechanism as is commonly assumed).

${ }^{113}$ On the capabilities of the Chinese legal profession, see generally STANLEY LUBMAN, BIRD IN A Cage: Legal Reform in China After Mao 157 (Stanford University Press 1999); Peerenboom, supra note 4, at 343-393. On the accounting profession, see TENEV \& ZHANG, supra note 57, at 120123.

114 See generally Brent Irvin, The Ecology of Corporate Governance in China (unpublished manuscript, 2005) (on file with author).

115 See Barney Jopson, Beïing in Overseas Accountany Deal, Financial Times (Internet ed.), July 25, 2006 (describing plans for foreign training of Chinese accountants and teachers of accountancy). 
errors" in 23 of them. ${ }^{116}$ So bad did things become that then-Premier Zhu Rongji called for foreign auditing firms to conduct supplemental audits of all listed firms in China. ${ }^{117}$ And the securities industry seems almost beyond redemption: a CSRC investigation revealed that in the notorious market manipulation scheme of Lü Liang, 125 securities firms actively assisted him. ${ }^{118}$

Lawyers and accountants cannot be expected to play a gatekeeping role if they bear little or no penalty for failing to do so. The system in China imposes few such penalties. While law firms and accounting firms may occasionally be sanctioned by the CSRC, I know of no lawsuits by misled investors against either. And firms seeking listings continue to use the same group of law and accounting firms without suffering any apparent penalty in the market. ${ }^{19}$

\section{Accounting Firms as Gatekeepers}

It is not simply their low level of accounting skills that prevents accounting firms from performing a gatekeeping role. A more important reason is that they simply have no strong incentive to do so.

Accountants can be subjected to legal sanctions in three ways: through criminal proceedings, through administrative proceedings, and in private litigation.

Civil liability of accounting firms for the general tort of certification of false financial information has developed only fitfully in the post-Mao era. An early set of State Council regulations from 1986 stated that accounting firms making false or improper certifications of matters such as financial statements and capital contributions were liable to administrative punishments of a warning, a fine, a suspension of business, or dissolution. ${ }^{120}$

Accountant liability was broadened at least in theory in 1994, when the Law on Registered Accountants provided that " $[\mathrm{w}]$ hen an accounting firm violates the provisions of this Law, causing losses to the engaging party (weituo ren) or another interested party (qita lihai guanxi ren), it should bear liability for compensation in accordance with law."121 In the modern Chinese legal system, however, broad language such as this can sometimes make courts reluctant, rather than eager, to read

116 See Bei Hu, Mainland Companies Are Reeling from a Year of Financial Scandals During Which the Audacity of Corporate Wrongdoers Has Put Their Western Counterparts to Shame, SouTH CHINA MoRnING Post, Mar. 26, 2002, at 1.

117 See Bei Hu, Tough Audit Rules Eased After Outcry from Interest Groups, South ChInA Morning Post, March 2, 2002, at B3; Richard McGregor, Creative Chinese Accounting Creates Work for Andersen, Financial Times, Jan. 28, 2002, at 20.

118 See Walter \& Howie, supra note 32, at 156-57.

119 See Irvin, supra note 114.

${ }^{120}$ See State Council, Zhonghua Renmin Gongheguo Zhuce Kuaijishi Tiaoli People's Republic of China Regulations on Registered Accountants], issued July 3, 1986, arts. 11, 27.

${ }^{121}$ Zhonghua Renmin Gongheguo Zhuce Kuaijishi Fa [Law of the People's Republic of China on Registered Accountants], adopted Oct. 31, 1993, effective Jan. 1, 1994, art. 42. 
expansive plaintiffs' rights into a statute. The Supreme People's Court then issued a series of instructions to lower courts to accomplish this task. ${ }^{122}$

Most recently, and presumably on the basis of lower-court experience with earlier interpretations, in 2007 the Supreme People's Court issued yet another interpretation, this time much lengthier and more detailed than its predecessors. ${ }^{123}$ This interpretation extended and clarified the conditions for accountant liability. First, it broadened liability to cover all inaccurate reports, not simply false certifications of contributed capital. Second, it repeated the principle that liability was limited to the amount falsely certified. Third, it defined the "interested party" of Article 42 of the Law on Registered Accountants as a party who, reasonably relying on or using an inaccurate report (defined broadly) issued by an accounting firm, engaged in a transaction with the audited firm or engaged in transactions with its stock or bonds and thereby suffered losses. Fourth, it provided that accounting firms could avoid liability if they could prove they were not at fault. Fifth - and remarkably - it provided that the accounting firm could still be liable even when the "interested party" had actual knowledge that the report was false and still used it, ${ }^{124}$ although the amount of the liability could be reduced "in accordance with circumstances" (zhuoqing).

Regulations in the field of securities have also targeted false certifications by accountants and others. The State Council's 1993 Provisional Regulations for the Administration of the Issuance and Trading of Securities, ${ }^{125}$ a proto-Securities Law, provided for fines and other administrative punishments for accountants and lawyers, among others, who provided false or misleading documents (Art. 73) and also called clearly for civil liability for damages caused to third parties by violation of the regulations (Art. 77). The 1998 Securities Law and its 2004 revision both contain

\footnotetext{
${ }^{122}$ See See Supreme People's Court, Guanyu Kuaiji Shiwusuo Wei Qiye Chuju Xujia Yanzi Zhengming Ying Rube Chuli de Fuhan [Reply Concerning How to Handle Cases in Which an Accounting Firm Issues a False Capital Contribution Verification Certificate for an Enterprise], issued April 4, 1996; Supreme People's Court, Guanyu Yanæi Danwei Dui Duoge Anjian Zhaiquan Ren Sunshi Ying Rube Chengdan Zeren de Pifu [Reply Concerning How a Capital-Verifying Body Should Bear Liability for Creditors' Losses in Multiple Cases], Jan. 13, 1998; Supreme People's Court, Guanyu Kuaiji Shiwusuo Wei Qiye Chuju Xujia Yanzi Zhengming Ying Rube Chengdan Zeren Wenti de Pifu [Reply Concerning the Question of How an Accounting Firm that Issues a False Capital Contribution Verification Certificate Should Bear Liability], issued June 26, 1998, effective July 1, 1998; Supreme People's Court, Guanyu Jinrong Jigou Wei Qiye Chuju Bushi Huогhe Xujia Yanzi Baogao Zijin Zhengming Rube Chengdan Minshi Zeren Wenti de Pifu [Reply of the Supreme People's Court on the Question of How Civil Liability Should Be Borne by Financial Institutions that Issue Inaccurate or False Capital Contribution Verification Certificates or Proofs of Funds], issued Feb. 9, 2002.

${ }^{123}$ See Supreme People's Court, Guanyu Shenli Sheji Kuaiji Shiwusuo Zai Shenji Yewu Huodong Zhong Minshi Qinquan Peichang Anjian de Ruogan Guiding [Several Rules on the Adjudication of Cases Involving Civil Tort Liability Incurred by Accounting Firms in the Course of Business Activities], issued June 11, 2007, effective June 15, 2007.
}

${ }^{124}$ It is not clear how the report could be said to have been "used" by someone who knew it was false.

${ }^{125}$ Gupiao Faxing yu Jiaoyi Guanli Zanxing Tiaoli [Provisional Regulations for the Administration of the Issuance and Trading of Securities], issued April 22, 1993. 
provisions stating that accountants and other intermediaries (including lawyers) who make false or misleading representations or certifications in the course of securities issuance or trading shall be subject to specified administrative sanctions, in addition to being civilly liable for damages. ${ }^{126}$ The 1993 Company Law (effective in 1994) and its 2005 revision also contain provisions on auditor liability in certain circumstances. ${ }^{127}$

In summary, then, a civil remedy against accounting firms appears to have been available since at least 1994. Nevertheless, it seems to have been rarely used. I have found only seven cases in the last ten years in which accounting firms have been found civilly liable for inaccurate certifications. ${ }^{128}$ All were suits by creditors who had dealt with the debtor firm in reliance on the inaccurate certification. In another seven cases, creditors brought suit on the same grounds but lost. In one case, a creditor won a re-trial after the first- and second-instance courts erroneously denied the legal basis of its claim. I found no cases in which buyers or sellers of a firm's securities sued an accounting firm for certifying inaccurate numbers as contemplated by the Supreme People's Court's 2007 interpretation.

Whatever its theoretical availability, therefore, the threat of private civil litigation from investors does not appear to be a realistic constraint on accounting firms in their work of auditing listed companies.

Administrative sanctions are equally rare, at least in the context of securities markets. In the four years from 2004 to 2007, the CSRC issued a total of 160 administrative punishments. In those actions, accountants were fined for certifying misleading financial information four times in 2004, three times in 2005, once in 2006, and three times in $2007 .{ }^{129}$ It may well be that the CSRC has

126 See Zhonghua Renmin Gongheguo Zhengquan Fa [Securities Law of the People's Republic of China], adopted Dec. 29, 1998, effective July 1, 1999, arts. 161, 189, 202; Zhonghua Renmin Gongheguo Zhengquan Fa [Securities Law of the People's Republic of China], as amended Oct. 27, 2005, effective Jan. 1, 2006, arts. $173 ; 223$.

The provisions on civil liability are vague and have been, as discussed elsewhere in this paper, considerably weakened through Supreme People's Court interpretative rulemaking. Nevertheless, in 2002, the Supreme People's Court specified that accountants and lawyers could be made defendants in civil suits for false disclosures under the Securities Law. See Supreme People's Court, Guanyu Shenli Zhengquan Shichang Xujia Chenshu Yinfa de Minshi Peichang Anjian de Ruogan Guiding [Several Rules on the Adjudication of Civil Suits for Compensation Brought About by False Disclosures in Securities Markets], issued Dec. 26, 2002, effective Feb. 1, 2003 (hereinafter False Disclosure Rules).

${ }^{127}$ See 1993 Company Law, supra note 34, art. 219; 2005 Company Law, supra note 34, art. 208.

${ }^{128}$ This does not, of course, mean that there were only seven such cases. Chinese cases are not systematically collected and reported, either officially or unofficially. See Donald C. Clarke, Empirical Research into the Chinese Judicial System, in Beyond Common KNOwledge: Empirical Approaches TO THE RulE OF LAw 166-67 (Erik Jensen \& Thomas Heller ed. 2003). The case sample discussed here was obtained from news reports and from a systematic search of the case law database of Chinalawinfo.com.

${ }^{129}$ These conclusions are based on the author's analysis of data available at the CSRC's Web site at www.csrc.gov.cn as of Feb. 23, 2008. The Web site further shows the following data on sanctions 
genuinely more pressing matters on which to spend its limited resources, but sanctioning accounting firms is apparently not a high priority.

Finally, criminal proceedings are almost non-existent. Article 229 of the Criminal Law punishes the intentional or grossly negligent provision of false certification of facts by lawyers and accountants, among others. ${ }^{130}$ Prosecutions, however, are rare. A search of two major legal databases ${ }^{131}$ turned up only six cases. A search of news sources turned up one more recent case. In this seven-case sample, three cases involved corporate insiders, and in one the defendant accountant was acquitted. Only three cases represent classic examples of liability for accountants for failing in their duty as gatekeepers. ${ }^{132}$ One of those ${ }^{133}$ stemmed from the Yin Guangxia case, a well-known corporate scandal comparable to Worldcom or Enron. ${ }^{134}$ Another was reported to be the first ever such case in Sichuan province. ${ }^{135}$

stronger than a warning in earlier years: 1993-1998: one; 1999: two; 2001: one; 2001: two; 2002: three; 2003: three.

${ }^{130}$ See Zhonghua Renmin Gongheguo Xing Fa [Criminal Law of the People's Republic of China], effective Oct. 1, 1997, art. 229.

131 The databases are available online at http:/ / www.chinalawinfo.com and http://www.lawyee.com.

${ }^{132}$ The three cases are that of Lu Lihe and Ding Yong, see Liang Zhuce Kuaijishi Chuju Zhengming Wenjian Zhongda Shishi Bei Pan Xing [Two Registered Accountants Sentenced for Issuing Gravely Inaccurate Certificating Documents], Feb. 26, 2006, available at http://www.chinacourt.org/public/detail.php?id=196439 (Basic-Level People's Court, Yiping District, Yibin Municipality, Sichuan) (hereinafter Lu Libe Case), that of Li Junyi, see Di Jianfeng Deng Xujia Zhuce Ziben An [The Case of Di Jianfeng et al. Involving False Registered Capital], available at http://vip.chinalawinfo.com/case/displaycontent.asp?gid=117446692 (Gansu Province, Kang County Basic-Level People's Court, Jan. 27, 2000), and that of the accountants in the Yin Guangxia scandal, see Dong Bo [et al.] Tigong Xujia Caikuai Baogao, Chuju Zhengming Wenjian Zhongda Shishi An [The Case of Dong Bo et al. Providing False Financial and Accounting Reports and Issuing Gravely Inaccurate Certificating Documents], available at http://vip.chinalawinfo.com/Case/displaycontent.asp?gid=117508210 (Ningxia Hui Autonomous Region Yinchuan Municipality Intermediate-Level People's Court, Sept. 3, 2003) (hereinafter Dong Bo Case).

${ }^{133}$ See Dong Bo Case, supra note 132.

${ }^{134}$ See, e.g., Hu Shuli, Enrons of China, Newsweek InTERnational, Dec. 1, 2004, 2004 WLNR 18089331 (Westlaw).

135 See Lu Libe Case, supra note 132. An official at the Sichuan provincial-level court stated that prosecutions for the crime in question were quite rare nationwide. See id. 


\section{Law Firms as Gatekeepers}

Like accountants, lawyers issue opinions in the context of securities offerings that must pass muster with the CSRC and on which investors are expected to rely. Also like accountants, lawyers face a low probability of sanctions for issuing irresponsible opinions on which investors rely to their detriment.

Some of the regulations already canvassed that cover misleading statements and certifications by accountants also cover lawyers in the same way. The Securities Law, for example, covers lawyers as issuers of legal opinions and possibly as securities market intermediaries, ${ }^{136}$ as did its predecessors and supplements, the 1993 Provisional Regulations for the Administration of the Issuance and Trading of Securities, ${ }^{137}$ the 1993 Provisional Measures Prohibiting Acts of Securities Fraud. ${ }^{138}$ and a 2002 interpretation of the Securities Law by the Supreme People's Court. ${ }^{139}$ In addition, a 1999 CSRC document on disclosure obligations states that lawyers should bear "appropriate legal liability" if they have not adequately checked the materials on which their legal opinions are based. ${ }^{140}$

Private litigation does not appear to play any role in disciplining lawyers. I have been unable to find any cases in which lawyers have been held liable for their part in disclosure violations, or even cases in which a law firm is listed as a defendant. Nor have I been able to find any criminal cases involving disclosure violations or other aspects of corporate governance.

The CSRC has occasionally imposed administrative sanctions on law firms for the part in disclosure violations. These are summarized in Table 1 below.

\section{[INSERT TABLE 1 HERE]}

A few points are worth noting about these sanctioning decisions. First, the data may be incomplete; some punishment decisions probably do not show up here. This very absence of publicity, however, makes sanctions less effective both as deterrents and in their shaming effect. Second, the disclosure violations in question all seem to have been discovered and corrected before the sale of stock to the public. In one case the CSRC simply felt that the offending firm's legal opinion was too vague; in addition to sending it back for more work, the CSRC imposed a punishment. Third, the CSRC got considerably tougher in the year 2000, issuing more, and more severe, punishments. Finally, the record of law firm punishments simply stops at 2000 for reasons

${ }^{136}$ See the provisions of the Securities Law cited in note 126 supra.

${ }^{137}$ Supra note 125 .

138 Jinzhi Zhengquan Qizha Xingwei Zanxing Banfa [Provisional Measures Prohibiting Acts of Securities Fraud, issued Sept. 12, 1993, abolished as redundant Jan. 15, 2008.

139 See False Disclosure Rules, supra note 126.

${ }^{140}$ See China Securities Regulatory Commission, Gongkai Faxing Gupiao Gongsi Xinxi Pilu de Neirong yu Geshi Zhunze Di Liu Hao (Falü Yijian Shu de Neirong yu Geshi) [Standards for the Content and Format of Information Disclosure by Companies Publicly Issuing Shares (Content and Format of Legal Opinion)], issued July 1, 1999, art. 4. Particularly in view of the reluctance of Chinese courts to hear shareholder suits, this is less than an unambiguous grant of a private right of action to shareholders against lawyers. It is unclear whether the CSRC, with less legal status than a ministry, can actually create civil liability. 
that are not clear. A study published in 2004 stated that as of that date, no punishments had been imposed for acts that took place after the coming into effect on July 1, 1999 of the Securities Law. ${ }^{141}$ One reason may be that since 2002, lawyer discipline has largely become the province of local government authorities and not the CSRC. Thus, disciplining decisions are taking place out of readily available public view. Clearly, further research is necessary.

\section{State Institutions for Corporate Governance (I): The Role of the CSRC}

The following sections of this article will look at state or quasi-state institutions and their capacity for making rules about corporate governance and discovering and sanctioning violations. They will also look at the particular types of violations that meet with sanctions. It must be remembered, however, that sanctioned violations are only a subset of actual violations. First, not all discovered violations are sanctioned; the sanctioning organization has its priorities, and will devote resources to certain areas it deems important to the relative neglect of others. Second, not all violations are even discovered. On the basis of a survey of listed companies and securities firms, one scholar concludes that for every sanctioned violation another one to four violations went undiscovered. ${ }^{142}$

Given the Chinese state's preference for government over private solutions, the CSRC is an obvious candidate for an important role in monitoring and enforcing corporate governance norms. It is therefore worth examining its powers in detail.

1. Regulatory Authority

\section{a. Regulatory Authority in General}

The CSRC has central and local offices that undertake a number of regulatory tasks, although the precise contours of the CSRC's regulatory authority are controversial.. The first general regulation in the field of securities - the State Council's Temporary Regulations on the Administration of Stock Issuance and Trading, ${ }^{143}$ considered still to be in effect today despite the existence of the Securities Law_-gave the CSC and the CSRC under it the authority to regulate "the securities markets" (zhengquan shichang) and provided that CSRC approval (among many others) was required for listing. The 1999 Securities Law, China's first comprehensive legislation on the subject, gave the CSRC the power to regulate issuers, securities markets, and market intermediaries, and allowed it to delegate certain regulatory functions to the exchanges, which nevertheless remained

\footnotetext{
${ }^{141}$ See Peng Bing, Zhengquan Lüshi Xingzheng Zeren de Shizheng Yanjiu [Empirical Research into the Administrative Liability of Securities Lanyers], FA SHAng YanjIU [STUdies IN LAw ANd Commerce], no. 6, 2004, at 16, 18.

${ }^{142}$ See Wu Xiaoliang, Zhengquan Fanzui Chengjie Yanjiu [Research into the Punishment of Securities Crimes], CAIjING, Internet ed., June 27, 2005 (reporting research of Professor Bai Jianjun of Beijing University Faculty of Law).

${ }^{143}$ State Council, Gupiao Faxing yu Jiaoyi Guanli Zanxing Tiaoli [Temporary Regulations on the Administration of Stock Issuance and Trading], issued Apr. 22, 1993 [hereinafter Stock Trading Temporary Regulations].
} 
under its tight control-the CSRC still appoints their leaders, for example. It confirmed the CSRC's approval power over public issuances of stock. ${ }^{144}$

At the core of the CSRC's authority over companies seeking listing or already listed is its regulation of their disclosure of information. Moreover, it has traditionally not been reluctant to review share offerings for substantive merit as well as for adequacy of disclosure. ${ }^{145}$ Indeed, until the end of 2005, a public listing was conditional upon the issuer's showing profits for the three preceding years.

Even disclosure itself is directed at the needs of merit review by a state agency, not at providing information to the investing public. The public has no right of access to disclosures made to the CSRC; instead, the law typically — but not always - provides that disclosures made to the CSRC must also be made in some designated public forum. ${ }^{146}$

\section{b. Corporate Governance Initiatives}

Beyond disclosure, the CSRC has interpreted its regulatory authority broadly, extending as far as attempting to exercise censorship over the financial press. Because this Article is concerned with corporate governance issues, it will look more narrowly at the CSRC's considerable initiatives in this area-initiatives that have gone well beyond the realm of disclosure regulation. Over the years the CSRC has issued numerous documents of varying and often uncertain degrees of binding force over the years. Although a full list would be otiose, a partial list in chronological order will afford some idea of the breadth of its regulatory reach.

- In 1994, the CSRC issued, jointly with the State Commission on Reform of the Economic System (SCRES), a document (the Mandatory Articles) containing provisions required in the articles of association of Chinese companies seeking permission to list outside the mainland (including in Hong Kong). ${ }^{147}$

${ }^{144}$ See Zhonghua Renmin Gongheguo Zhengquan Fa [Securities Law of the People's Republic of China], effective July 1, 1999, superseded Jan. 1, 2006 [hereinafter 1999 Securities Law], art. 10; Securities Law, supra note 146, art. 10.

145 See Sheng Xuejun, Woguo Zhengquan Jianguan Falü Zhidu Moshi [The Legal System Model of Securities Regulation in China], Xiandai Faxue [Modern Law Science], No. 3, 2001, at 116, 117; Zhu, supra note 160 , at 181.

${ }^{146}$ A person required by the Securities Law to make a tender offer must submit to the CSRC a report containing various details of its intentions, but need only announce to the public the fact of its offer. See 1999 Securities Law, supra note 144, art. 82; Zhonghua Renmin Gongheguo Zhengquan Fa [Securities Law of the People's Republic of China], as amended Oct. 27, 2005, effective Jan. 1, 2006, art. 89 [hereinafter Securities Law].

147 See China Securities Regulatory Commission and State Commission for Restructuring Economic Systems, Guanyu Zhixing "Dao Jingwai Shangshi Gongsi Zhangcheng Bibei Tiaokuan de Tongzhi” [Notice on Implementing the "Mandatory Articles of Association for Companies Listing Abroad"], Zheng Wei Fa (1994) No. 21, Aug. 27, 1994 [hereinafter Mandatory Articles]. 
- In 1997, it took issued what was essentially a domestic counterpart to the 1994 Mandatory Articles, the Guidance Articles of Association for Listed Companies ${ }^{148}$ —in effect, a miniCompany Law. The Guidance Articles were revised and reissued in 2006. ${ }^{149}$

- In 1999, together with the State Economic and Trade Commission (SETC), it issued further guidelines on corporate governance in companies listed abroad in the Opinion on Further Promoting the Normalized Operation and Deepened Reform of Companies Listed Abroad. ${ }^{150}$ Like the 1997 Guidance Articles, the Opinion went deep into the heart of traditional corporate governance territory, purporting to impose a duty of loyalty and diligence upon directors. ${ }^{151}$

- In August 2001, it issued its Guidance Opinion on the Establishment of an Independent Director System in Listed Companies. ${ }^{152}$ Covering all companies listed on Chinese stock exchanges (but not Chinese companies listed overseas), the Opinion required all listed companies to have a one-third independent board by mid-2003 and called for the independent directors to have various powers.

- In a January 2002 notice addressed to listed companies, the CSRC issued its Principles of Corporate Governance for Listed Companies. ${ }^{153}$ Contemporary commentary stated that the Principles were based on the OECD Principles of Corporate Governance, as modified by appropriate principles drawn from specific foreign jurisdictions and China's own particular situation. ${ }^{154}$

${ }^{148}$ China Securities Regulatory Commission, Guanyu Fabu "Shangshi Gongsi Zhangcheng Zhiyin" de Tongzhi [Notice on the Issuance of the "Guidance Articles of Association for Listed Companies"], Zheng Jian (1997) No. 16, Dec. 16, 1997 [hereinafter 1997 Guidance Articles].

149 See China Securities Regulatory Commission, Guanyu Yinfa "Shangshi Gongsi Zhangcheng Zhiyin (2006 Nian Xiuding)" de Tongzhi [Notice on the Printing and Distribution of the "Guidance Articles of Association for Listed Companies (2006 Revision)'], Zheng Jian Gong Si Zi (2006) No. 38, Mar. 16, 2006 [hereinafter 2006 Guidance Articles].

${ }^{150}$ State Economic and Trade Commission and China Securities Regulatory Commission, Guanyu Jinyibu Cujin Jingwai Shangshi Gongsi Guifan Yunzuo he Shenhua Gaige de Yijian [Opinion on Further Promoting the Normalized Operation and Deepened Reform of Companies Listed Abroad, Guo Jing Mao Qi Gai (1999) No. 230, Mar. 29, 1999 [hereinafter Opinion on Further Reform].

151 See id., sec. 3.

${ }^{152}$ China Securities Regulatory Commission, Guanyu Zai Shangshi Gongsi Jianli Duli Dongshi Zhidu de Zhidao Yijian [Guidance Opinion on the Establishment of an Independent Director System in Listed Companies], issued Aug. 16, 2001 [hereinafter Independent Director Opinion]. The Opinion and related issues are discussed thoroughly in Clarke, supra note 60.

${ }^{153}$ China Securities Regulatory Commission, Shangshi Gongsi Zhili Zhunze [Principles of Corporate Governance for Listed Companies], art. 21, issued Jan. 7, 2002 hereinafter Corporate Governance Principles].

${ }^{154}$ See Shan Yuqing, Youguan Zhuanjia Zhichu Shangshi Gongsi Zhili Jiegou de Quexian Shi Zhongguo Ziben Shichang Fazhan Mianlin de Juda Tiaozhan [Relevant Experts Point Out that Shortcomings in the Governance 
- In December 2004, it issued Several Provisions on Strengthening the Rights and Interests of Public Shareholders. ${ }^{155}$ The Provisions contain a number of corporate governance rules aimed directly at abuses by controlling shareholders that had come to be perceived by the policy community (probably correctly) as rampant. Most significantly, the Provisions contained voting rules on certain matters that directly contradicted specific rules in the Company Law.

The degree of the CSRC's authority to regulate in the field of pure corporate governance, as it were, is not completely clear. There are some grounds for its assertion of wide authority. The 1995 Temporary Regulations on Stock Trading included among the conditions for listing "other conditions stipulated by the Securities Commission" (i.e., the CSC) without indicating any limitations on the CSC's ability to prescribe conditions, thus apparently giving it carte blanche. ${ }^{156}$ The 1999 Securities Law also allowed the CSRC to require the submission of whatever documents it deems relevant, again without any apparent limitation. ${ }^{157}$ The 2005 Securities Law, however, requires State Council approval of CSRC-imposed conditions, possibly in response to a sense that the CSRC had been going well beyond its traditional mandate. ${ }^{158}$

As far as statutory texts are concerned, therefore, it is difficult to find any specific limitation on the subject matter of the CSRC's jurisdiction. The statutes granting regulatory authority to the CSRC do contain language that could - if one wished-be read as imposing at least some broad limitations: the 1993 Stock Trading Temporary Regulations, the 1999 Securities Law, and the 2005 Securities Law all state that the CSRC (or the CSC) has authority to regulate "the securities markets". ${ }^{159}$

Some academic commentators have questioned whether the CSRC has authority to make any rules at all. They argue that the CSRC is an "institutional unit" (shiye danwer), not a fully-fledged administrative department under the State Council authorized by the Constitution to formulate

Structure of Listed Companies Are a Great Challenge Facing the Development of Capital Markets in China], Zhongguo Jingui Shibao [China Economic Times], July 9, 2001; Tang Xin, Zhongguo Shangshi Gongsi Zhili Huanjing De Xin Fazhan [New Developments in the Governance Environment for Chinese Listed Companies] (Paper for 21st Century Commercial Law Forum, Tsinghua Univ., Beijing, Nov. 18, 2001).

${ }^{155}$ China Securities Regulatory Commission, Guanyu Fabu "Guanyu Jiaqiang Shehui Gongzhong Gu Gudong Quanyi de Ruogan Guiding" de Tongzhi [Notice on the Issuance of the "Several Provisions on on Strengthening the Rights and Interests of Public Shareholders"], Zheng Jian Fa (2004) No. 18, Dec. 7, 2004 [hereinafter Public Shareholder Provisions].

156 Stock Trading Temporary Regulations, supra note 143, art. 8(7). To my knowledge, no serious argument has been made in China that the CSRC did not succeed to this grant of authority to the CSC.

157 See 1999 Securities Law, supra note 144, art. 11.

158 See Securities Law, supra note 146, arts. 12, 13.

159 See Stock Trading Temporary Regulations, supra note 143, art. 5; 1999 Securities Law, supra note 144, art. 7; Securities Law, supra note 146, art. 7. 
regulations within its sphere of competence. ${ }^{160}$ It exercises delegated power, and thus can only apply rules, not make them. ${ }^{161}$ Still less, they argue, can it make rules providing for the imposition of punishments such as banning. ${ }^{162}$

Ultimately, efforts to undertake a legal analysis of the CSRC's powers arguably miss the point by assuming that such an analysis is meaningful in the Chinese legal system. Chinese administrative agencies simply do not act according to a model of legally defined subject matter competence. ${ }^{163}$ The CSRC has such power as it can successfully assert. The main limitations on its authority are probably better understood as political, not legal.

\section{Enforcement Tools}

The CSRC tries to induce compliance with its wishes with a number of tools of varying effectiveness. Its two key weapons are (a) its power to review applications for public share offerings and to grant or refuse permission, ${ }^{164}$ and (b) its power to investigate and punish violations of laws and regulations relating to securities. ${ }^{165}$ Sometimes it threatens to use these powers; other times, intriguingly, it does not. Still other times it simply declares that certain acts will not be valid under certain conditions, but it does not automatically follow that other government agencies in China, particularly courts, will give effect to that declaration if it seems to go beyond the CSRC's authority.

\section{a. Refusal to Approve Applications for Stock Issuance}

Standards for listing can be enforced in a straightforward way: the CSRC can refuse to approve applications that do not meet such standards, and indeed the exposition of those standards may not even need to contain the threat of non-approval. For example, the 1994 Mandatory Articles ${ }^{166}$ contain no explicit threat of non-approval where a company applying to list shares abroad submits a non-conforming version of its articles of association; it is perhaps too obvious to require stating.

${ }^{160}$ For a fuller discussion of this issue, see SANZHu Zhu, SECurities Regulation in China 5354 (2000).

${ }^{161}$ See Zhou Weixin, Zhongguo Zheng Jian Hui "Zhengquan Shichang Jinru Zhidu Zanxing Guiding” de Quexian Pingxi [An Critique of the Shortcomings of the CSRC's "Temporary Rules on Prohibiting Entry to the Securities Market'], Faxue [Legal Science], No. 4, 1998, at 60, 61.

${ }^{162}$ See id. at 62.

${ }^{163}$ This and the following propositions are not self-evident; unfortunately, there is insufficient space here to establish them by argument.

164 See 1999 Securities Law, supra note 144, art. 10; Securities Law, supra note 146, art. 10.

165 See 1999 Securities Law, supra note 144, art. 167; Securities Law, supra note 146, art. 179.

${ }^{166}$ Mandatory Articles, supra note 147. 


\section{b. Refusal to Accept Applications for Stock Issuance or Other Matters}

Distinct from a refusal to approve applications is a refusal to accept them. In Chinese legal and administrative practice, "acceptance" of an application (or petition, or lawsuit) by a governmental body is a formal act; the term could be translated "docketing". Thus, making an application involves more than simply submitting the necessary documents. It also involves a formal acceptance of the submission by the authority to which the application is made. Many of the CSRC's regulatory documents are accompanied by the threat that non-compliance by companies will be punished by the CSRC's refusal, for a given time period, to accept applications respecting the various matters over which the CSRC has approval power, most notably (but not necessarily) the issuance of stock.

\section{c. Fines}

The CSRC's power to impose fines is set forth in detail in Chapter 11 of the Securities Law, which lists a series of specific offenses based on the rules spelled out elsewhere in the statute for which the CSRC may impose a fine. Because the Securities Law does not specify internal corporate governance standards, however, it follows that it does not prescribe fines for violations of such standards. Nor does it give the CSRC carte blanche to impose fines whenever the CSRC's own rules are violated. Nevertheless, the CSRC has threatened fines for violation of corporate governance standards. In the 1996 Listed Company Standards, for example, non-compliance was stated to be punishable by fines under the "relevant provisions" of the 1993 Stock Trading Temporary Regulations. ${ }^{167}$ But it is hard to find any "relevant provisions" in the Regulations justifying fines for the acts prohibited by the Standards. ${ }^{168}$

\section{d. Banning from the Market}

The sanction of banning from the market was first introduced by the CSRC in 1997 with the Temporary Rules on the Prohibition of Entry into Securities Markets; ${ }^{169}$ a revised version entitled Rules on the Prohibition of Entry into Securities Markets ${ }^{170}$ appeared in June 2006. Among other things, the Temporary Rules and their successor provide that persons can be prohibited, either for a limited time or for life, from serving as senior officer, director, or supervisor in a listed company. Although no punishment is stated for persons who defy the ban, listed companies that employ such persons in defiance of the ban are subject to unstated administrative sanctions to be imposed by the

167 See China Securities Regulatory Commission, Guanyu Guifan Shangshi Gongsi Xingwei Ruogan Wenti de Tongz̧hi [Notice on Several Issues in Standardizing the Behavior of Listed Companies], Zheng Jian Shang Zi (1996) No. 7, July 24, 1996, I 7 [hereinafter Listed Company Standards].

168 See Stock Trading Temporary Regulations, supra note 143, art. 70.

${ }^{169}$ See China Securities Regulatory Commission, Guanyu Yinfa "Zhengquan Shichang Jinru Zanxing Guiding" de Tongzhi [Notice on the Printing and Distribution of the "Temporary Rules on the Probibition of Entry into Securities Markets'], issued Mar. 3, 1997 [hereinafter Market Entry Probibition 1997].

${ }^{170}$ China Securities Regulatory Commission, Zhengquan Shichang Jinru Guiding [Rules on the Probibition of Entry into Securities Markets], issued June 7, 2006 [hereinafter Market Entry Probibition 2006]. 
CSRC. ${ }^{171}$ The CSRC may also refuse to accept their applications for approvals on any matter, and may direct the exchanges to suspend trading in their stock. ${ }^{172}$ Curiously, these enforcement mechanisms were all removed from the 2006 successor version of the Temporary Rules. The only stated enforcement mechanism in the 2006 Rules is a public announcement of the banning and a record in the individual's "good-faith file" (chengxin dang'an) maintained by the CSRC.

The Temporary Rules provided a list of offenses, ${ }^{173}$ the list did not, however, specifically include any related to internal corporate governance, although it did include a catch-all at the end for "serious violations of securities laws, [administrative] regulations, [ministry-level] rules, and relevant CSRC rules." 174 Thus, if the CSRC made rules about internal corporate governance, it could under the Temporary Rules punish their violation with a ban on market entry. This seems to have been what the CSRC had in mind when it promulgated its Several Provisions on Strengthening the Rights and Interests of Public Shareholders. ${ }^{175}$ The Provisions declare that senior management personnel have a duty of good faith and loyalty, and threaten to ban from the market those who violate it.

The sanction of banning received a firmer basis in Article 233 of the Securities Law as revised in 2005, but it is still not clear how banning would be enforced against a defiant party.

\section{e. Reprimands and Other Soft Sanctions}

Finally, a few words should be said about reprimands, warnings, and similar sanctions. On their face, they would seem of doubtful effectiveness, and they do not seem to be feared by corporate and individual wrongdoers. To the extent that a corporate officer is in effect a state official — and that will be true in certain companies closely connected to the state - a reprimand or warning could hurt his or her chances for further promotion within the civil service. ${ }^{176}$ But as corporate officials become more just like private businesspersons, the effect of such sanctions can be expected to decrease.

In 2002, the CSRC announced the establishment of the "good faith file" system. ${ }^{177}$ According to then-Vice Chairman Laura Cha, directors, supervisors, and senior officers who

${ }^{171}$ See id., art. 17. The basis upon which the CSRC could have imposed such sanctions is not clear, given that they are not specified in the document itself.

172 See id., art. 5.

173 See Market Entry Probibition 1997, supra note 169, art. 4. Possibly due to a drafting oversight, the CSRC did not in the Temporary Rules give itself the power to prevent malefactors not already officers, directors, or supervisors from becoming such. This was corrected in the 2006 Rules.

${ }^{174}$ Market Entry Probibition 1997, supra note 169, art. 4(7).

175 See note 155 supra and accompanying text.

${ }^{176}$ This explanation of the punitive effect of a reprimand was suggested to me by a CSRC official.

${ }^{177}$ See Zheng Jian Hui Jianli Zhengquan Shichang Canyu Zhuti de Chengxin Dang'an [CSRC Establishes Good Faith File System for Securities Market Participants], Xinhua Wang [XINHuA NeT], April 23, 2002, at http://news.xinhuanet.com/zhengfu/2002-04/23/content_368574.htm; see also Zaogao de Chengxin Jilu [The Mess of Good Faith Records], IT Jingli Shijie [IT Manager's WorLd], Nov. 20, 2004, at 20. 
committed violations of "good faith" (chengxin) would, in accordance with listing rules, have their qualifications to hold their posts "restricted" (xian₹hi). Furthermore, listed companies found guilty of violations of good faith would find that when the CSRC accepted (shouli) their reports on various matters, it would "consider" their good faith record in order to raise the costs of violations. ${ }^{178}$

Following up on the CSRC's lead, in 2004 the Shenzhen Stock Exchange announced the establishment of a good-faith file system of its own for small and medium-sized enterprises. According to the governing regulations, violations of good faith by listed companies and their officers, directors, and supervisors would be recorded and made public. ${ }^{179}$

Needless to say, this is all very vague, and the CSRC's jurisdiction to judge and punish the violation of such a nebulous duty is questionable. In fact, however, so far as the records of CSRC actions on its Web site shows, as of the end of 2007 the CSRC had not once imposed a punishment for what might be called a violation of the duty of good faith per se. Nor did the record of the Shenzhen Stock Exchange as of that date appear very different: every report of a sanction that I examined was for a disclosure violation — that is, a violation of the Securities Law — and nothing less legally solid.

Thus, the "good faith file" system seems to be more about putting a general name to a method of recording sanctions for violations of statutory duties than about judging and punishing a new kind of duty.

\section{f. "Comply or Explain"}

The CSRC has occasionally adopted a more flexible "comply or explain" approach to its corporate governance standards. This, for example, is the approach taken, at least as a formal matter, by the 2002 Principles of Corporate Governance for Listed Companies. ${ }^{180}$ Although the CSRC would probably not wish to label them optional, Article 91 seems to contemplate that corporate governance practices may diverge from those called for in the Principles, and requires disclosure of the existence of and reasons for such divergence. Logically, however, if the rest of the Principles are not mandatory, it is hard to see how the disclosure requirement itself could be mandatory. ${ }^{181}$

\footnotetext{
178 See id.

179 See Shenzhen Stock Exchange, Shenzhen Zhengquan Jiaoyisuo Zhong-Xiao Qiye Ban Shangshi Gongsi Chengxin Jianshe Zhiyin [Shenzhen Stock Exchange Guidelines for the Establishment of Good Faith in Listed Companies on the Small and Medium Enterprise Board, June 24, 2004, available at http://www.szse.cn/Web/Article/2004/12/30/1755343437C6615.aspx.
}

${ }^{180}$ China Securities Regulatory Commission, Shangshi Gongsi Zhili Zhunze [Principles of Corporate Governance for Listed Companies], issued Jan. 7, 2002.

${ }^{181}$ By way of contrast, consider the mechanics of the comply-or-explain approach in other countries. In Germany, for example, a governmental commission produced the German Corporate Governance Code. The comply-or-explain rule, however, is contained not in the Code, which is not mandatory, but in the Public Corporations Act. See Aktiengesselschaften [Law on Stock Corporations] \$ 161, translated in COMMERCIAL LAws of THE World: Germany (rev. ed. 1995); see generally Klaus J. Hopt \& Patrick C. Leyens, Board Models in Europe: Recent Developments of Internal 
In some jurisdictions, the "comply or explain" approach is used because regulatory authorities recognize that what might be a good idea most of the time is not a good idea all of the time, and that case-by-case judgment by an informed market is superior to a strict rule. The effectiveness of this approach, however, has been questioned. ${ }^{182}$

\section{Summary: What Role Can the CSRC Play in Corporate Governance?} follows:

In terms of corporate governance, the CSRC's tasks and powers can be summed up as

- It reviews offering documents for conformity with disclosure requirements and substantive merit.

- It formulates rules and recommendations regarding both disclosure and internal corporate governance.

- It attempts to monitor the implementation of the above rules and recommendations and to discourage violations.

These tasks are in addition to its many other tasks, such as regulating stock exchanges and market intermediaries and indeed intervening in the market when it deems it necessary. ${ }^{183}$ In other

Corporate Governance Structures in Germany, the United Kingdom, France, and Italy \2.1 (European Corporate Governance Institute, Working Paper No. 18/2004, Jan. 2004), available at http://ssrn.com/abstract $=487944$.

${ }^{182}$ See Eric Nowak, Roland Rott \& Till G. Mahr, The (Ir)relevance of Disclosure of Compliance with Corporate Governance Codes_Evidence from the German Stock Market (Swiss Finance Institute Research Paper Series, April 27, 2006), available at http://ssrn.com/abstract $=9202010$ (finding that firm value is unaffected by announcements of firms" compliance behavior); Iain MacNeil \& Xiao Li, "Comply or Explain": Market Discipline and Non-Compliance with the Combined Code, 14 CORP. Gov. 486 (2006) (finding that "investors do not value reasoned arguments for non-compliance and prefer to use financial performance as a proxy to determine when non-compliance can be excused").

${ }^{183}$ There is no doubt that the CSRC sees as one of its tasks the support of the market: Not only retail investors, but also many government officials, remain of the view that the proper function of securities markets is to go up: the CSRC has been criticized for causing markets to fall through overenthusiastic enforcement. Even the CSRC itself is wary of overregulation — not in the sense of making too many rules, but in the sense of enforcing existing rules - for precisely the same reason. Many in the financial services industry argue that a certain amount of willful blindness on the part of regulators is necessary, at least at the current stage, for public confidence to continue because that confidence is driven more by a continually rising market than by knowledge that corporate governance is sound.

Donald C. Clarke, Peter Murrell \& Susan Whiting, The Role of Law in China's Economic Development, in China's Great Economic Transformation 375, 420 (Thomas Rawski \& Loren Brandt ed. 2008); see also sources cited at note 70, supra. As part of its mission to support markets, for example, in August 1994 the CSRC imposed a freeze on new stock issues in order to raise stock prices by restricting supply. See ZHU, supra note 160, at 183. And in May 2008, the CSRC threatened to punish mutual fund managers who dumped shares along with other investors during a market downturn. See Daniel Ren, Beijing Resorts to Threats to Stop Stocks Slide, South ChinA Morning Post, May 31, 2008, available at 2008 WLNR 10266925 (Westlaw). 
words, the CSRC has much to keep it busy, and a key question is whether it can perform its various missions effectively.

As the above review of documents issued by the CSRC has shown, it is not reluctant to tell listed companies how they should manage their internal affairs. Yet the review of enforcement actions actually taken by the CSRC, at least insofar as they appear in the public record, suggests that it actually devotes very few resources to ensuring that such internal corporate governance norms are actually put into practice.

A technique the CSRC has often used is to require_-or at least to attempt to require-listed companies to adopt certain norms as part of their articles of association instead of purporting to enact those norms directly as regulations. It did so with the Mandatory Articles, ${ }^{184}$ where its authority to do so was unquestioned, but also with documents of more uncertain legitimacy.

Take, for example, the 1997 Guidance Articles. ${ }^{185}$ These were contained in a notice that was addressed to the securities regulatory offices of local governments at the provincial level. ${ }^{186}$ Declining to attempt to enforce the implementation of these guidelines itself, the CSRC asked local governments to ensure that companies under their jurisdiction amended their articles of association to reflect the guidelines. Similarly, in the Independent Director Opinion, ${ }^{187}$ the CSRC called for independent directors to have various powers, but attempted to realize this goal through having companies write these powers into their articles of association or other internal rules.

Many commentators treat such norms as if they were mandatory norms of corporate governance in China. In fact, they are twice removed from the level of binding norm. First, whether companies in fact amend their articles of association in conformity with the CSRC's wishes is an open question that has not to my knowledge been studied. Second, even if companies do amend their articles of association, those articles, like any other set of rules, are meaningless without an enforcement mechanism.

The CSRC does not directly enforce corporate articles of association; the enforcement mechanism, if any, is private litigation in courts-probably on what is essentially a contract theory - by plaintiffs injured by a failure to follow the rules. My own research has so far failed to uncover a single case in which plaintiffs won a lawsuit for the infringement of rights derived only from the articles of association. ${ }^{188}$ If the articles of association of listed companies do in fact contain all the desired rules, then either they are being followed faithfully or else they are simply not justiciable

${ }^{184}$ Mandatory Articles, supra note 147.

1851997 Guidance Articles, supra note 148.

${ }^{186}$ It was also addressed to the governments of certain cities that are treated as provinces for economic planning purposes and hence have provincial status in certain cases.

${ }^{187}$ Independent Director Opinion, supra note 152.

188 Thus, I am not counting cases where the norm that was violated-for example, a rule of equal treatment for all shareholders in the distribution of dividends - is stated both in the articles and in law. 
as a practical matter. Since the first alternative seems unlikely, it is thus far from clear that the CSRC's back-door route to the enforcement of corporate governance norms is at all effective.

What, then, about the front-door route? Does the CSRC use its punishment power to back up its corporate governance norms? Here the answer is clearly no. From 2002 through 2007, the CSRC issued a total of 211 punishment decisions (chufa jueding). ${ }^{189}$ Of those, 99 were for disclosure violations involving listed companies or their officers, directors, or supervisors. None was for a violation of substantive rules of corporate governance, whether derived from the Company Law or from rules issued by the CSRC itself.

It may be that enforcement actions are few because the need is small. But it is more likely either that the CSRC is aware that it is on uncertain legal ground and thus prefers to resort to informal jawboning, or that it simply cannot do everything and has made a policy decision to concentrate its energies on other matters, such as misappropriation of client funds by securities companies.

There is also a third possibility that cannot be overlooked: that the CSRC's hesitancy about strong enforcement action in the realm of corporate governance is part and parcel of its general unwillingness to enforce standards in its core competence of securities regulation. This unwillingness stems from its dual mission as market regulator and market promoter for the state. If the securities markets are not paying good money for issues of SOE stock, then the CSRC is not doing its job, and if clamping down on abuses would hurt the markets—for example, by obstructing the flow of funds into the market from illegal sources - then the CSRC may not have the political will to do so. It is not because the regulatory framework is inadequate. ${ }^{190}$

Whatever the reason for the general lack of enforcement, one conclusion seems clear: corporate governance norms that rely on the CSRC for implementation may not turn out to be terribly meaningful in the Chinese corporate world.

\section{E. State Institutions for Corporate Governance (II): The Stock Exchanges}

China has two stock exchanges: one in Shenzhen and one in Shanghai. I discuss them under the heading of "state institutions" because they were created by government and operate under even tighter government control than a public utility. Despite their ostensibly self-regulatory nature, their leading personnel are directly appointed by the CSRC, ${ }^{191}$ and it is not possible for private citizens to

${ }^{189}$ See Table 3 at page 59 infra, where I discuss CSRC punishment decisions from a different angle.

190 This point is developed in greater detail in GREEN, supra note 41, at 28-29. My own experience confirms this. During a series of meetings I attended in 2005 with persons involved in the drafting of the 2005 Securities Law, the complaint was often heard that the CSRC was unable to clamp down on illegal activity because it lacked various powers under the Securities Law then in effect. In many cases, however, an examination of the law revealed that the CSRC did indeed have the powers in question; the problem was that it was unwilling or unable to use them.

${ }^{191}$ See the interviews and sources cited in Liebman \& Milhaupt, supra note 7, at fn. 17. 
establish any new markets. ${ }^{192}$ Thus, they cannot be studied as a civil-society institution arising as a market response to some social demand.

The stock exchanges have available four sanctioning methods, which are, in ascending order of seriousness, oral warnings, letters of oversight, criticism notices, and public criticisms. ${ }^{193}$ The exchanges may also designate individuals as unsuitable to serve as certain officers and directors of listed companies. ${ }^{194}$

According to the most comprehensive study to date of stock exchange sanctions, each of the two exchanges typically issues a few dozen warnings and criticism notices-neither of which is public_-per year. In 2006, the Shanghai Stock Exchange issued 716 letters of oversight (again, nonpublic), although in previous years it had never issued more than 153. Between 2001 and 2006, the Shanghai Stock Exchange issued 109 public criticisms against 89 different companies, while the Shenzhen Stock Exchange issued 149 public criticisms against 116 different companies. ${ }^{195}$

It is difficult to assess the effect of stock exchange sanctions on corporate governance. Liebman and Milhaupt characterize public criticisms as shaming sanctions, and find that they are effective. ${ }^{196}$ But it is not clear what rules or standards such sanctions enforce. The stock exchanges have promulgated listing rules as well as a variety of other rules and standards - mostly relating to disclosure, but a few relating to what might be called internal corporate governance as well ${ }^{197}$ — but the specific conduct that will result in sanctions, while known internally, is not made public:

Exchange officials state that their decision not to make the standards public is due to the fact that the Chinese market "is not sophisticated"; officials are concerned that if companies were aware of the specific standards, they might manipulate their disclosure so as to avoid sanctions. ${ }^{198}$

The opacity of the sanctioning standards, as well as the fact that few of the published rules deal with internal corporate governance matters, means that at present the stock exchanges cannot be considered an effective institution for creating or implementing norms of corporate governance.

\section{F. State Institutions for Corporate Governance (III): The Court System}

192 See generally id. at 4.

${ }^{193}$ See id.

${ }^{194}$ See id.

${ }^{195}$ See id.

196 See generally id.

${ }^{197}$ For example, the Shanghai Stock Exchange has issued rules on training for independent directors, see Shanghai Zhengquan Jiaoyisuo Shangshi Gongsi Duli Dongshi Peixun Guanli Banfa [Shanghai Stock Exchange Administrative Measures on the Training of Independent Directors in Listed Companies], March 23, 2006, available at http://tinyurl.com/6mxk88, and on the conduct of board meetings in listed companies, see Shanghai Zhengquan Jiaoyisuo Shangshi Gongsi Dongshihui Yishi Shifan Guize [Shanghai Stock Exchange Model Rules on the Conduct of Board of Directors Meetings in Listed Companies], May 12, 2006, available at http://tinyurl.com/6mxk88.

${ }^{198}$ Liebman \& Milhaupt, supra note 7. 


\section{Introduction}

What kind of role can Chinese courts play in a corporate governance regime? There are a number of tasks for which courts would seem, based on the experience of other jurisdictions, to be likely candidates.

A corporate governance regime will typically mix bright-line rules (for example, shareholder voting requirements for particular transactions) with broad standards such as good faith or reasonableness. Neither type of norm, of course, will mean anything unless there is a body than can apply it with skill and reasonable consistency.

Courts are generally considered the most appropriate body to enforce broad standards such as fiduciary duty because they have the tools to understand the factual background of the dispute in detail and because they can develop, whether formally or informally, a kind of jurisprudence based on actual experience.

Whether Chinese courts can do so, however, is questionable. Chinese legal theory has traditionally been resolutely against the development of any kind of case law by courts - the pupil in this case surpassing the teacher, the civil law systems of Europe, in adherence to this dogma. ${ }^{199}$ Judges in any case are not accustomed to giving reasoned opinions of the kind that would allow the development of a case law-based jurisprudence. ${ }^{200}$

Second, Chinese courts are subject to the principle of horizontal accountability in the political system: judges owe their positions to local, not central, political authorities. ${ }^{201}$ When this fact is combined with the principle that a plaintiff must generally sue in the court of the defendant's domicile, ${ }^{202}$ local judicial protectionism becomes possible. If the defendant is a listed corporation, the odds are that it is largely owned and controlled by the local government where the court sits. If the defendants are executives of the corporation, they are probably also locally influential people. Because the courts are accountable to local political power, it will be difficult for outside plaintiffs to win when they are opposing that power.

But the chief obstacle may simply be the policy question of whether it is wise to give the Chinese judiciary, with its low level of education and vulnerability to corruption and political

\footnotetext{
${ }^{199}$ Recently some movement on this issue has become visible. See, e.g., Donald C. Clarke, Zhengzhou Court Experiments With System of Precedent, Chinese Law Prof Blog, Oct. 21, 2005, at http://lawprofessors.typepad.com/china_law_prof_blog/2005/10/zhengzhou_court.html; Fu Weiwei \& Zhang Xuliang, Shilun Woguo Anli Zhidao Zhidu zhi Goujian [A Tentative Discussion of the Establishment of the Case Guidance System in China], FALÜ SHIYOng [AppliCATION OF LAw] (Journal of the National College of Judges), No. 1, 2006, at 16.

${ }^{200}$ But see Colin Hawes, Seeds of Dissent: The Evolution of Published Commercial Law Court Judgments in Contemporary China, 5 Australian J. Asian L. 1 2003) (showing growth in some areas of reasoned opinions).

201 See Donald C. Clarke, Power and Politics in the Chinese Court System: The Execution of Civil Judgments, 10 Columbia J. Asian L. 1, 41-49 (1996).

${ }^{202}$ As, for example, they must when suing for misleading disclosures.
} 
pressure, an important role to play in the development of Chinese corporate governance norms. There is a cost to be paid in forgoing the use of broad standards, to be sure: bright-line rules are invariably over- or under-inclusive, and rule out the very quality of judgment for which we look to courts. But there is also a cost to be paid in relying for their elaboration on a body incapable of doing so competently.

Indeed, courts in China have shown themselves unreliable as enforcers even of relatively clear standards. As discussed elsewhere, they are simply reluctant to get themselves involved in litigation relating to large corporations. Even after the SPC slightly opened the door it had previously closed on shareholder litigation for Securities Law violations, actual judgments against defendants have been rare and perhaps non-existent. ${ }^{203}$

\section{The Courts and the CSRC}

It is important to understand in detail how CSRC procedures and the court system work together in the context of corporate governance-related litigation.

The CSRC has authority under the Securities Law to impose punishments for violation of its provisions ranging from warnings through fines. Understanding its use of this authority is vital for understanding not only the role of government in corporate governance, but also the role of private litigation. This is because a very significant amount of private litigation based on violations of the Securities Law cannot take place unless the CSRC or other government agency has issued an official punishment. ${ }^{204}$ That condition was imposed in 2003 by the Supreme People's Court in its Several Provisions on the Adjudication of Civil Suits for Damages Arising out of False Representations in Securities Markets. ${ }^{205}$ This document was the third of a series of SPC regulations having the collective effect of barring courts from accepting any shareholder suits under the Securities Law bringing claims of fraud (including, apparently, false or misleading disclosures), insider trading, or market manipulation except where certain conditions were met: in particular, that the suit was for misleading disclosure and that there had been a finding to that effect in the form of a criminal conviction or an administrative punishment imposed by the CSRC or some other government agency.

In short, to get in the courthouse, plaintiffs must typically first get a key from the CSRC in the form of an official punishment for misleading disclosure. How likely are they to get such a key? The evidence suggests not often.

A 1999 Chinese study covering the period from October 1993 to December 1998 shows very little enforcement action against misleading disclosures. ${ }^{206}$ In that period, the CSRC issued a

${ }^{203}$ See, e.g., Katharina Pistor \& Chenggang Xu, Governing Stock Markets in Transition Economies: Lessons from China 13 (Nov. 2004), available at http://ssrn.com/abstract $=628065$.

${ }^{204}$ As I will show below, this statement is a slight oversimplification.

${ }^{205}$ Supreme People's Court, Guanyu Shenli Zhengquan Shichang Yin Xujia Chenshu Yinfa de Minshi Peichang Anjian de Ruogan Guiding [Several Provisions on the Adjudication of Civil Suits for Damages Arising out of False Representations in Securities Markets], issued Jan. 9, 2003.

${ }^{206}$ See Bai Jianjun, Zheng Jian Hui 60 ge Chufa Jueding de Shiæheng Fenxi [An Empirical Analysis of 60 CSRC Punishment Decisions], Faxue [Legal Studies], No. 11, 1999, at 55-62. 
total of 60 punishment decisions in the area of securities issuance and trading (not including futures). Most of the cases were for price manipulation, for which under the SPC's 2003 Provisions there is now no private remedy. Moreover, only $26.7 \%$ of the cases were against issuers; $43.3 \%$ were against securities firms and $8.3 \%$ against other intermediaries. Fewer than $15 \%$ of the punishments were issued for misleading disclosure.

Pistor and Xu present data from later years showing punishments imposed by the CSRC, the Shanghai and Shenzhen Stock Exchanges, and other administrative agencies; the picture is much the same (see Table 2). ${ }^{207}$

\section{[INSERT TABLE 2 HERE]}

Under the 2003 SPC Provisions, punishments imposed by the exchanges or for acts other than misleading disclosures do not provide a key to the courthouse, and so these numbers will overstate to an unknown degree the potential for private litigation; they represent the maximum number of violations for which damages in a court action could be sought.

The numbers do not look promising. In 2003, for example, the number of punishment actions reported by Pistor and Xu (eleven) was less than one percent of the number of listed companies. According to Pistor and $\mathrm{Xu}$, the sanctions were usually benign, with warnings quite frequent. ${ }^{208}$ Furthermore, the actions seem to have been mostly against securities firms, not against listed companies or their officers.

Even after the issuance of the SPC's 2003 Provisions, the number of punishment decisions for disclosure violations satisfying the conditions of the Provisions remains low. The following table shows in the second column formal punishment decisions from 2002 (because such decisions could have been used as the basis of a private suit under the 2003 Provisions) through the end of 2007 (reported as of Feb. 23, 2008). The third column shows which of these decisions might, under a liberal interpretation, have satisfied the conditions of the Provisions and enabled a shareholder to bring a lawsuit. ${ }^{209}$

\section{[INSERT TABLE 3 HERE]}

The 2003 SPC Provisions also provide a key to the courthouse where a defendant has been sanctioned by another administrative agency or held criminally liable. Although precise statistics on

\footnotetext{
207 See Pistor \& Xu, supra note 203, at 33. There seem to be problems with the Pistor and Xu data or its interpretation. They report 51 enforcement actions by all relevant regulatory agencies in 2003, of which only 11 were punishments. The CSRC's Web site, however, shows that it issued 40 punishments in 2003. See http://www.csrc.gov.cn (CSRC Web site). Similarly, Pistor and Xu report eight punishment decisions by all agencies in 2003, whereas the CSRC's Web site reports 17 issued by the CSRC alone.

208 See Pistor \& Xu, supra note 203, at 33.

${ }^{209}$ The numbers in this column cannot be wholly objective and are based on my own analysis of the decisions.
} 
such cases are not available, knowledgeable plaintiffs' lawyers put the number of such additional potential defendants at about twenty. ${ }^{210}$

It is hard to know what kind of standard these numbers should be measured against to make them meaningful. Nevertheless, it seems plausible to conclude that the number of courthouse keys being distributed by the CSRC (and other government agencies) is small indeed. According to a recent study, despite the existence of approximately 110 qualifying punishments, only about twenty companies had been sued during the period the Supreme People's Court lawsuit limitations have been in effect. ${ }^{211}$ While one company may have been punished more than once, in which case 110 qualifying punishments do not necessarily imply 110 suit-eligible companies, it seems fair to think that many more than twenty companies could have been sued. When one recalls that to be suiteligible means that an authoritative state agency has already made an authoritative finding that misleading disclosures were in fact made, the number of companies actually sued seems small.

Among the lawsuits that have been filed, a small number have reached the stage of judgment or settlement; only a few have resulted in judgments for plaintiffs. ${ }^{212}$ Moreover, after getting a judgment in their favor, plaintiffs often find that enforcing it is another matter entirely. ${ }^{213}$

\section{Shareholder Derivative Suits}

As a final way of understanding the role of courts, this section will examine shareholder derivative suits as a detailed case study of the relationship between institutions and norms of corporate governance.

Robert Clark has labeled the shareholder derivative suit "one of the most interesting and ingenious of accountability mechanisms" for large corporations. ${ }^{214}$ In China, however, doctrinal and political obstacles have severely limited its usefulness as a device for policing management malfeasance. At the same time, lawsuits essentially derivative in nature have occasionally been allowed, despite the lack of the clear legal basis generally required by Chinese courts. Whether the losses inflicted by unpredictability in corporate law are outweighed by the gains of management accountability is not clear. But the uncertainty surrounding derivative suits has been greatly reduced by recent amendments to the Company Law specifically allowing them in certain circumstances.

\footnotetext{
${ }^{210}$ See Liebman \& Milhaupt, supra note 7.

${ }^{211}$ See id.

${ }^{212}$ See id.
}

${ }^{213}$ See Clarke, supra note 201 (discussing difficulties in enforcing judgments in China); but see Xin He, Enforcing Commercial Judgment in the Pearl River Delta of China, __ J. EMPIRICAL LEG. STUD. (forthcoming 2008) (finding that, at least in the Pearl River Delta, "the enforcement outcomes are reasonable, the enforcement process is relatively efficient, the problem of local protectionism is not serious, and the plaintiffs' impressions of the courts have also been quite positive").

214 See Robert C. Clark, Corporate Law \ 15.1 (1986). For a skeptical view, see Roberta Romano, The Shareholder Suit: Litigation Without Foundation?, 7 J. L. ECON. \& ORG. 55, 84 (1991) (concluding that shareholder litigation, including derivative litigation, "is a weak, if not ineffective, instrument of corporate governance"). 
Allowing such suits to proceed in one statutorily defined channel may have the effect of stopping up other less well-defined channels and thereby increase predictability.

\section{a. Doctrinal Bases}

Derivative suits need a special doctrinal basis because the chairman of the board of a company (or its executive director in the case of a company with no board of directors) occupies a special position in Chinese corporate law as essentially the personification of the company: the "legal representative" (fading dabiao ren). ${ }^{215}$ As such, he is more than a mere agent of the company and cannot be stripped, by board action or otherwise, of his ability to act in its name. His signature is both necessary and sufficient for the company to act as a plaintiff in litigation. ${ }^{216}$ Consequently, if his interests will be hurt by the lawsuit - most obviously, if he is a defendant-he will not agree and it cannot, barring some exception to the normal rule, proceed.

(1) 1993 Company Law

China's first Company Law, adopted in 1993, is generally considered not to have provided for derivative suits. ${ }^{217}$ The most promising section, Article 111, reads in its entirety as follows:

\footnotetext{
If the resolutions of a shareholders' meeting or board of directors violate laws or administrative regulations and [thereby] infringe the legitimate rights and interests of shareholders, the shareholders shall have the right to institute proceedings with a people's court requesting the cessation of such illegal activities and acts of infringement.
}

\footnotetext{
${ }^{215}$ For an excellent discussion of the special position of the legal representative, see Fang Liufang, Guoqi Fading Daibiaoren de Falü Diwei, Quanli be Liyi Chongtu [The Position, Powers, and Conflicts of Interest of the Legal Representative in State Enterprises], BijiaO FA YANjIU [RESEARCH IN COMP. LAW], No. 3, 1999, available at http://www.civillaw.com.cn/weizhang/default.asp?id=9199
}

${ }^{216}$ See Zhonghua Renmin Gongheguo Minshi Susong Fa [Civil Procedure Law of the People's Republic of China], adopted and effective Apr. 9, 1991, art. 49 (hereinafter Civil Procedure Law); Supreme People's Court, Guanyu Renmin Fayuan Shouli Jingii Jiufen Anjian Zhong Jige Wenti de Fuhan [Reply Letter Concerning Some Issues in the Acceptance by People's Courts of Economic Dispute Cases], issued Nov. 14, 1990, 11 (directing courts to send back for supplementation any complaint not bearing the signature of an enterprise's legal representative). Prof. Fang Liufang writes:

If the legal representative won't go along, the legal person [i.e., the company] has no way to initiate or participate in litigation; if the legal representative on his own initiative takes part in litigation, there are no grounds for preventing him from exercising the right to sue on behalf of the company.

Fang, supra note 215.

217 See Jiong Deng, Building an Investor-Friendly Shareholder Derivative Lawsuit System in China, 46 HARV. INT'L L.J. 347, 356-68 (2005), and sources cited therein. 
Some commentators have read this as providing the grounds for a derivative action, ${ }^{218}$ while others disagree. ${ }^{219}$ From both a textual and a practical standpoint, the skeptics seem to have the stronger argument; the differences between an Article 111 lawsuit and a true derivative suit are clear. First and most obviously, under Article 111 shareholders sue in their own name, not in the name of the company. Second, only a right to require cessation of the infringing act is clearly stated; a right to recovery of damages is not. ${ }^{20}$ Third, the only acts that may be complained of are unlawful resolutions of the shareholders or the board of directors. This excludes not only lawful resolutions that may nevertheless in some way cause actionable damage to the shareholders, but also a vast universe of acts and omissions that do not take the form of resolutions: all failures to act as well as actions taken by corporate officers and others without a board or shareholders' resolution.

Other sections of the 1993 Company Law spell out statutory duties of officers and directors to the company, ${ }^{221}$ and Article 63 states that directors, supervisors, and managers ${ }^{222}$ shall be liable for damages caused to the company by their violation of law, administrative regulations, or the company's articles of association. But it fails to state that shareholders may enforce this liability on the company's behalf if the company fails to do so. More pertinently, courts entertaining derivative suits in China have not generally found a basis for them in Article 63.

\section{(2) 1999 Securities Law}

China's first Securities Law, ${ }^{223}$ issued and effective in 1999 (since replaced by a substantially amended version effective from Jan. 1, 2006 ${ }^{224}$ ), has been thought by some to support derivative litigation, but again the claim is weak, especially in view of the failure of courts to support it. Article 42 provides that gains from short-swing (i.e., within a six-month period) trading by a five percent shareholder shall belong to the company and shall be recovered in an action initiated by the board of directors. It further states that shareholders may request the board to take action if it fails to do so, and that directors responsible for a failure to take action shall be liable for losses thereby caused to the company. Once again, however, it fails to spell out that shareholders may step into the shoes of a recalcitrant board and sue in the name of the company.

${ }^{218}$ See, e.g., Kong Xianguun, Min Shang Fa Redian Nandian Ji Qianyan Wenti [Hot, Difficult, and Cutting-Edge Issues in Civil and Commercial Law] 248 (Renmin Fayuan Chubanshe 1996), cited in Deng, supra note 217, at 356 (view of senior judge at Supreme People's Court).

${ }^{219}$ See, e.g., Deng, supra note 217, at 356-58, and sources cited therein.

${ }^{220}$ This point is made by Prof. Gu Gongyun in Gu Gongyun, Gongsi Fa Xinding de Ruogan Jianyi [Several Suggestions Regarding the Amendment of the Company Law], SHAngshi Gongsi [Listed Company], No. 5, 2000.

${ }^{221}$ See, for example, Articles 59 to 62 of the 1993 Company Law.

${ }^{222}$ The term "manager" (jingli) here probably means chief executive officer. Chinese does not distinguish between singulars and plurals.

2231999 Securities Law, supra note 144.

${ }^{224}$ Securities Law, supra note 146. 
(3) Principles of Corporate Governance for Listed Companies

In January 2002, the China Securities Regulatory Commission issued its Principles of Corporate Governance for Listed Companies. ${ }^{225}$ Article 4 of the Principles states that in certain cases of management wrongdoing, "[s] hareholders have the right to request (yaoqiu) ${ }^{226}$ that the company bring litigation according to law requesting (yaoqiu) compensation."

Although some commentators have stated that the Principles provide a legal basis for derivative suits, ${ }^{227}$ the argument seems weak. The sentence in question contains no hint of what is to happen if the company rejects the shareholder's request to bring litigation. As Chinese courts are as likely as not to interpret their jurisdiction narrowly in order to avoid nettlesome cases, this lacuna is significant.

More importantly, however, the Principles simply are not law. They are a set of standards that the CSRC desires listed companies to implement in their articles of association. Whether the CSRC has the authority to force companies to do so is debated; the fact that it wishes companies to do so, however, suggests that stating the norms in the Principles is not sufficient to make them operational.

\section{(4) 2004 Beijing Higher People’s Court Opinion ${ }^{228}$}

In February 2004, the Beijing Higher Court issued its Guidance Opinion on Several Issues Relating to the Adjudication of Corporate Dispute Cases, ${ }^{229}$ which like the draft Supreme People's Court Provisions deals with derivative suits, but which unlike them purports to be effective upon issuance. Article 8 of the Opinion, in question-and-answer format, states in its entirety:

How should the parties be ascertained when a shareholder brings suit on the grounds that the company's interests have been harmed by the improper behavior of a shareholder or company management personnel? This type of litigation is the kind where a shareholder represents the company's interests in bringing suit; the company shareholder may be the plaintiff, while the defendants are the shareholder or company management personnel who engaged in the improper acts and the opposite party in related transactions. The company should participate in the litigation as a third party.

${ }^{225}$ Corporate Governance Principles, supra note 153.

${ }^{226}$ The term used here, yaoqiu, can mean request or demand (i.e., a request coupled with a right to compliance). Given other examples of the term in Chinese legislation, I believe that here it means merely "request" without an associated right to satisfaction.

227 See, e.g., Xuan Weihua \& Li Chen, Shangshi Gongsi Zhili Zhunze Ruogan Wenti Pingxi [Comments on Several Issues Relating to the Principles of Corporate Governance for Listed Corporations], SHANGSHI GONGSI [Listed Company], No. 7, 2002, available at http://www.people.com.cn/GB/paper87/7526/721417.html.

${ }^{228}$ Chinese courts and other government agencies frequently issue documents labeled yijian; although this term is customarily translated "opinion", it means something like a suggestion, and should not be confused with "opinion" meaning a formal decision issued by a judge to decide a case.

${ }^{229}$ Beijing Higher People's Court, Guanyu Shenli Gongsi Jiufen Anjian Ruogan Wenti de Zhidao Yijian [Guidance Opinion on Several Issues Relating to the Adjudication of Corporate Dispute Cases], adopted Feb. 9, 2004, issued and effective Feb. 24, 2006. 
As the document is called a "Guidance Opinion", it is not clear how far the Beijing Higher People's Court (the highest court in Beijing, which has the administrative status of a province) wishes to bind the courts under it. I believe courts would have remained free to reject such suits had they wished to do so, thus making derivative claims essentially discretionary. At the same time, however, the Opinion represents the first unambiguous declaration from a legally authoritative body that derivative suits can, at least in some circumstances, be accepted by courts.

\section{(5) Supreme People's Court Policy}

Finally, it is worth mentioning an informal signal from the Supreme People's Court. In December 2002, a senior Supreme People's Court judge stated that courts should accept derivative suits. ${ }^{230}$ These remarks were cited hopefully by one plaintiff; his suit was nevertheless rejected by a lower court, which informed him that such remarks were "for reference" only and could not constitute a basis for accepting the suit. ${ }^{231}$

\section{b. Cases}

Despite their unpromising doctrinal foundation, derivative suits are not unknown in China. In the following cases, courts considered and occasionally accepted arguments that the shareholder plaintiff should be able, against the wishes of another shareholder that controlled the company's ability to litigate, to sue another party (sometimes that shareholder) for damages inflicted directly on the company. It is interesting to note that where the courts accepted the argument, they did not attempt to impose any limiting principle on such arguments; all they seem to have required was a plausible allegation of damage to the company and a refusal by the controlling party to seek recovery of those damages. ${ }^{232}$

${ }^{230}$ See Gao Fayuan Fuyuaņhang Li Guoguang Biaoshi: Xiao Gudong Gao Da Gudong Fayuan Ying Shouli [Supreme People's Court Vice President Li Guoguang Indicates that Courts Should Accept Suits by Small Shareholders Against Large Shareholders], Beijing Yule Xinbao [Beijing Recreation News], Dec. 12, 2002, available at http:/ / news.sohu.com/58/64/news204906458.shtml.

231 See Shouli Gudong Daibiao Susong Wei Bei Shouli [First Shareholder Representative Suit Is not Accepted, Shanghai Zhengquan Bao [Shanghai Sec. News], Apr. 22, 2003, available at http://101.stock888.net/030422/100,101,78015,00.shtml (hereinafter cited as First Shareholder Suit); see also Qian Weiqing, Gongsi Susong —Gongsi Sifa Jiuji Fangshi Xin Lun (6) [Corporate Litigation: A New Discussion of Methods of Judicial Remedies for Companies (6)], May 23, 2003, at http://article.chinalawinfo.com/article/user/article_display.asp?ArticleID=25304.

${ }^{232}$ Another quasi-derivative suit case not discussed here for reasons of space is the Taishan Company case discussed at Zhang Rulian \& Wang Ling, Ben An Gudong Shifou You Quan Chongdang Yuangao Daibiao Gongsi Tiqi Susong [Does the Shareholder in This Case Have the Right to Take the Role of Plaintiff and Bring Suit on Behalf of the Company?], Renmin Fayuan Wang [People's Court Net], May 31, 2004, at http://www.chinacourt.org/public/detail.php?id=117915. 
(1) Zhangjiagang Fiber Company Case

The first generally known case of the post-Mao era was a 1993 suit brought in Jiangsu Province by the Zhangjiagang Polyester Fiber Factory ("Factory"). ${ }^{233}$ Factory had joined together with a Hong Kong company, Jixiong Corporation ("Jixiong") to form a Chinese-foreign equity joint venture called Zhangjiagang Jixiong Chemical Fiber Company ("JV") in which Jixiong was the controlling party. JV had then entered into a contract with another Hong Kong company, Daxing Engineering Company ("Daxing"), in which Jixiong had an interest of an unspecified nature. When a contract dispute arose, Jixiong refused to cause JV to bring suit against Daxing. Factory then brought suit in a local court in Jiangsu Province seeking to bring suit on behalf of JV.

The question of Factory's standing ultimately went to the Supreme People's Court, which responded that Factoty could indeed exercise the litigation rights of $\mathrm{JV}$, but in this particular would not be able to do so because of a pre-existing arbitration agreement. ${ }^{234}$ Thus, the case did not actually result in a derivative suit being heard, even though its acceptability in at least some cases was established in principle. How far the reasoning of the Court's reply reaches has never been clear; given how the Court chose to entitle it, it could be read as applying narrowly to Chinese-foreign equity joint ventures controlled by a foreign party. Although it seems to have been cited in a subsequent purely domestic case, ${ }^{235}$ in general courts have been far from interpreting it as an encouragement, let alone a command, to accept derivative suits.

\section{(2) Shanghai Yanzhong Water Company Cases}

In 1996 and 1997, a widely publicized and complex series of lawsuits involving the Yanzhong Drinking Water Company tested the appetite of the Shanghai courts for derivative suits. ${ }^{236}$ Ultimately the plaintiff's attempt to bring such a suit was rejected.

The Yanzhong cases pitted a minority (30\%) shareholder (Yanzhong), which controlled the chairman of the board, against the majority $(60 \%)$ shareholder (Zhongtian), which had a majority of board seats and controlled the general manager (i.e., the CEO). Both attempted to cause the company to bring a lawsuit that they would control to their own advantage; both such lawsuits were dismissed. A lawsuit by Zhongtian in its own name against Yanzhong for damages caused to the

${ }^{233}$ The facts of this case are taken from Deng, supra note 217, at 365 n.108, and Supreme People's Court, Guanyu Zhongwai Heri Jingying Qiye Duiwai Fasheng Jingï Hetong Jiufen, Kongzhi Heying Qiye de Waifang yu Maifang You Lihai Guanxi, Heying Qiye de Zhongfang Ying Yi Shei de Mingyi Xiang Renmin Fayuan Qisu Wenti de Fuhan [Reply Letter on the Issue of in Whose Name the Chinese Party to a Chinese-Foreign Equity Joint Venture Should Bring Suit When the Joint Venture Has an Economic Contract Dispute with an External Party and the Foreign Party Controlling the Joint Venture Has a Relationship of Interest with the Seller], issued Nov. 4, 1994, available at http://www.people.com.cn/zixun/flfgk/item/dwjjf/falv/9/9-1-4-01.html (hereinafter SPC Reply on Derivative Suits).

${ }^{234}$ See id.

${ }^{235}$ See the Wu Fang Zhai case, discussed in Part IV.F.3.b.(4) infra.

${ }^{236}$ The facts of this case are taken from Deng, supra note 217, at 366-367; it is discussed in numerous Chinese sources, including Fang, supra note 215. 
company brought a doctrinally unsatisfactory result: while acknowledging the applicability of the Supreme People's Court's Reply in the Zhangjiagang Fiber Company Case, the court allowed the majority shareholder both to sue and to recover in its own name in the approved settlement; another minority $(10 \%)$ shareholder received nothing.

(3) Xiamen Xinda Network Company Case

In May 1997, the Xiamen Xinda Network Company (Network) was formed by three Chinese investors: Xiamen Xinda Company (Xinda), Century Manpower Company (Century I) and Century Communications Company (Century II) (essentially the same party), and Hualun Company (Hualun). ${ }^{237}$ Century I and Century II collectively had the power to appoint two directors; Xinda could appoint two, and Hualun could appoint one. After Century I and Century II refused to repay a loan from Network, the three non-Xinda directors rejected Xinda's call for a meeting of the board of directors to authorize action in pursuit of the debt. Xinda then brought suit, naming as defendants Century I and Century II as well as Network.

Unlike many other cases, this case presents a clear victory for a derivative suit theory. Not only did the plaintiff win in the first instance, but the victory was upheld on appeal with a specific reference to that theory:

If the infringement suffered by the shareholder is to the rights of the company, then the shareholder should
first present a written application to the organ of power of the company requesting that the company take
action or bring litigation against the party inflicting the harm and pursue its legal liability. Where the company
does not take any action, the shareholder may in its stead bring a lawsuit. ${ }^{238}$

(4) Zhejiang Wu Fang Zhai Company Case

In December 2000, Zhu Chuanlin entered into an agreement with the Jiaxing Commercial Holding Company (Holding) to purchase its 50\% holding in the Wu Fang Zhai Company (Wu Fang Zhai), a joint stock company. ${ }^{239}$ He later brought suit against Zhao Jianping, the chairman of Wu Fang Zhai, alleging that Zhao had caused Wu Fang Zhai to guarantee the debt of a stockholder in

\footnotetext{
${ }^{237}$ The facts of this case are taken from Xie Zhihong \& Chen Mingtian, Gudong Paisheng Susong Zai Sikao [Rethinking Shareholder Derivative Suits], Fujian Zheng-Fa Guanli Ganbu Xueyuan Xuebao [Journal of the Fujian Political-Legal Administrative Cadre Institute], No. 4, 2001, at 24, 24. One of the authors is an assistant judge in the Fujian Higher People's Court, where he presumably ran across this case.

${ }^{238} I d$. (summarizing court's reasoning).

${ }^{239}$ The facts of this case are taken from Luo Peixin, Gongsi FA De Hetong Jieshi [A Contractual Interpretation of Company Law] 335-36 (Beijing Daxue Chubanshe 2004). Further detail can be found at Lu Xiaoping, Dongshichang Zi Tao Yaobao Pei $250 \mathrm{~W}$ an; Zhiyi Wu Fang Zhai Shijian [Chairman of the Board Compensates 2.5 Million From His Own Wallet; Questions About the Wu Fang Zhai Case], Caijing Shibao [FinanCe And Economy Times], July 27, 2001, available at http:// finance.sina.com.cn/g/20010727/88091.html; Dou Shi Danbao Re de Huo; Dongshiøhang Bei Gudong Gaodao [A Disaster All Caused by a Guarantee; Chairman of the Board Brought Down by Shareholder Suit], Jiancha Ribao [Procuratorial Daily], July 27, 2001, available at http://www.chinalawinfo.com/fldt/xwnr.asp?id=2185.
} 
violation of Article 147 of the Company Law, and that Wu Fang Zhai had been forced to pay the debt-2.6 million yuan-after the stockholder defaulted.

Ruling in Zhu's favor, the court found that although the Company Law at that time had no specific provisions allowing for shareholder derivative suits, "the principle is clear" from viewing Articles 63 and 111 together. Moreover, it found that the 1994 Supreme People's Court Reply in the Zhangjiagang Fiber Company case ${ }^{240}$ constituted a precedent. ${ }^{241}$

\section{(5) San Jiu Pharmaceutical Company Case}

Not all attempts at derivative suits were successful. In April 2003, a shareholder of Shanghai-based San Jiu Pharmaceutical Company brought suit in Shenzhen's Futian Basic-Level People's Court against Zhao Xinxian, a director of the company, for damages he had inflicted on the company through related-party transactions and through disclosure failures that had resulted in fines to the company of 500,000 yuan. ${ }^{242}$ After the court rejected his suit, the shareholder refiled in the same month in the name of the company in Shenzhen's Intermediate People's Court. That court, however, refused to hear his suit on the grounds that the right to sue in the company's name required the agreement — apparently unanimous — of all the shareholders. ${ }^{243}$ Even requiring the consent of the majority-precisely those who had been involved in the misappropriation-would have made further prosecution of the suit impossible. Still less could unanimous consent be achieved.

\section{c. Derivative Suits in the New Company Law}

The new Company Law, ${ }^{244}$ adopted in October 2005 and effective as of January 1, 2006, finally provides a sound statutory basis for derivative suits, albeit with certain limitations. According

${ }^{240}$ SPC Reply on Derivative Suits, supra note 233.

${ }^{241}$ The direct and indirect quotations from the court's decision come from LuO PEIXIN, supra note 239, at 335. I have been unable to find a copy of the court's judgment.

${ }^{242}$ Zhao had already been fined 100,000 yuan by the CSRC in related proceedings for various transgressions. The facts of this case are taken from Deng, supra note 217, at 371, Wu Hanqing, Gudong Daibiao Susong de Zai Sikao [Rethinking the Shareholder Representative Suit, GuANGDONG CAIJING Zhiye Xueyuan Xuebao [Journal of the Guangdong Vocational Academy of Finance And Economics], Vol. 2, No. 6 (Dec. 2003), at 83-86, and China Securities Regulatory Commission, Xingzheng Chufa Jueding Shu (San Jiu Yi Yao ji Xiangguan Renyuan) [Administrative Punishment Decision (San Jiu Pharmaceutical and Related Persons)], Zheng Jian Fa Zi (2002) No. 12, July 4, 2002. For more detail on the specific acts, see Gongmeng Chen, Michael Firth, Daniel N. Gao \& Oliver M. Rui, Is China's Securities Regulatory Agency a Toothless Tiger? Evidence from Enforcement Actions, 24 J. Accounting \& Public Policy 451, 481-82 (2005).

${ }^{243}$ In order to avoid a formal decision that could be appealed, the court notified the plaintiff's lawyer solely through a telephone call. See First Shareholder Suit, supra note 231. This procedure makes plausible the suspicion that the decision may have had less to do with the merits than with the local political clout of the company's management.

2442005 Company Law, supra note 34. 
to Article 152, shareholders holding 1\% singly or collectively may, depending on the circumstances, make a demand on the board of directors or the board of supervisors to sue under Art. 150 of the Company Law, which imposes liability for compensation on any director, supervisor, or senior manager who causes losses to the company by violating "laws, administrative regulations, or the articles of association during the course of performing his duties[.]" If the company does not bring suit within thirty days, they may bring suit in their own name.

It is too early to know how Article 152 will be implemented in practice. As it offers very little by way of procedural guidance, a court not disposed to hear such cases will find a ready justification for inaction. Like the case law and quasi-legislative material preceding it, however, Article 152 appears to allow suits automatically provided only that shareholders satisfy certain procedural requirements. There is no apparent room for courts to consider an argument that bringing suit would not be in the interests of the company.

Even though derivative suits are now formally allowed, economic obstacles remain. When the recovery is to the company, the minority shareholder-who will benefit from the recovery only in proportion to his shareholding-has little incentive to bring suit unless he can recover his costs off the top. While Chinese law generally awards trial costs to the winner, such costs are usually defined only as funds paid to the court as filing and other fees, and do not include attorneys' fees. ${ }^{245}$

Other commentators have suggested the establishment of a foundation that would own shares in every listed company. ${ }^{246}$ Corporate governance litigation through similar non-profit organizations has proved reasonably successful in South Korea, Taiwan, and Japan; ${ }^{247}$ whether the model can be transplanted to a country in which the government keeps tight control over civil society institutions remains to be seen.

\section{Conclusion}

This article has examined the institutional environment in China for corporate governance institutions understood in a narrow sense: those that operate to mitigate both vertical and horizontal agency costs and attempt to align the interests of those who manage money with those who supply it. It has lessons for existing literature in the field of comparative corporate governance and in turn takes from lessons from it.

First, this article bears on the LLSV literature that attempts to measure legal institutions through law on the books, typically as embodied in statutes. Although criticism of this literature for

${ }^{245}$ See Wu Yanfen, Lun Woguo Minshi Susong Feiyong Zhidu de Gaige yu Wanshan [On the Reform and Perfection of the System of Civil Litigation Costs in China], Guangxi Xingzheng Guanli Ganbu Xueyuan Xuebao [journal of the Guangxi Administrative Management Cadre College], No. 5, 2004, at 82, 84.

246 See, e.g., Liang Dingbang (Anthony Neoh), Cong Zhengquan Jianguan Jiaodu Kan Gongsi Fa Xiugai [Viewing the Amendment of the Company Law from the Angle of Securities Supervision], in GUO \& WANG, supra note 104, at 29-34; Jiang Ping, Gongsi Fa Cong 19 Shiji Dao 20 Shiji de Farhan [The Development of Company Law from the 19th to the 20th Century], in GUO \& WANG, supra note 104, at 21.

247 See generally Curtis Milhaupt, Nonprofit Organizations as Investor Protection: Economic Theory, and Evidence from East Asia, 29 YALE J. INT'L L. 169 (2004). 
ignoring the law as it actually functions is not new, one contribution of this article is to show specifically and in detail just how far and why, in one important jurisdiction, law on the books turns out to be very hard to measure - which "books," for example, does one actually observe? — and to diverge considerably from practice. This is not to say that the task of measuring legal inputs and outputs is entirely hopeless and cannot possibly yield valid results, but it is to suggest that the measurement is extremely difficult, and must be done with far more sensitivity to local conditions than has been apparent so far. That this will be costly and make it hard to accumulate data for dozens of countries is unfortunate, but no less true for being unfortunate.

Second, it bears on, and takes lessons from, the literature on comparative institutional choice. Pistor and $\mathrm{Xu}$ argue that administrative agencies are in principle suited to certain legal tasks, whereas other tasks are in principle best left to courts. ${ }^{248}$ In their model, administrative agencies engage in ex ante, comprehensive rule-making and rule enforcement, whereas courts engage in ex post dispute settlement. They argue that the criteria for selecting institutions (as between administrative agencies and courts) should be the degree to which the law needs further elucidation and interpretation (which they call incompleteness), the ability to standardize potentially harmful or beneficial actions such that an administrative agency could engage in ex ante enforcement, and the level of expected harm if a violation is not prevented (by ex ante action) or deterred (by the prospect of ex post action). And they conclude that fiduciary duty obligations in particular are best assigned to courts for enforcement, since they cannot be standardized and yet at the same time have a low potential for severe harm, since they are by their nature limited to one company. ${ }^{249}$

As Pistor and Xu acknowledge, however, allocating certain tasks to courts as called for by their model may be pointless if courts are ineffective because of corruption, lack of political power, or other reasons, and thus extensive institutional reform may first be required. ${ }^{250}$ This caveat certainly seems to apply to China. To the extent the policy advice presupposes extensive institutional reform, however, it loses its value as advice about incremental policy changes that can be undertaken now on a platform of existing institutions.

Thus, for all the attention it receives, the shareholder rights approach described in Part II-indeed, any approach that relies upon formal legal institutions-cannot be expected to form the mainstay of an effective corporate governance regime. The courts have neither the power nor the inclination to play a major role, and government agencies such as the CSRC do not have the resources to serve as a substitute.

Nor does the ownership approach hold out much hope. At present, dominant shareholders seem either to abuse their control or to fail to exercise it entirely. There are two possible ways in which these problems could be remedied. The state could improve its internal management system so that it became a more effective monitor in the companies it dominated. Such a reform is imaginable, but fails to address the issue of abuse of control. The control of abuses rests ultimately, like the shareholder rights approach, on legal institutions — and as argued above, legal institutions are a weak reed on which to rely.

\footnotetext{
${ }^{248}$ See Pistor \& Xu, supra note 6.

${ }^{249}$ See Pistor \& Xu, supra note 21.

${ }^{250}$ See id.
} 
Unfortunately, the best available substitute approach, that of market monitoring, is disfavored by the state. The Chinese state prefers direct regulation by government agencies first, and indirect regulation by private litigation in the state's courts next. Regulation by the uncontrolled institutions of the market comes a distant third, and indeed it is hard to find such institutions in China. The stock markets are creatures of the state and exist only upon its sufferance; securities firms are established and owned by various governmental bodies; banks are either directly owned or else highly controlled by governmental bodies; the financial press is subject to significant state influence, both through ownership channels and through the state's pervasive regulation of the media.

In a state with limited administrative resources, it would make sense to rely as far as possible on the contributions of non-state actors. But Chinese corporate governance institutions are tilted toward the legal because the government generally suspects the institutions of the market and civil society in general. It wants rules, not incentive structures. There is a strong emphasis on getting the rules right, and an inadequate attention to institutions that could be flexible in creating and enforcing rules as the situation warranted. ${ }^{251}$

Troy Paredes has cogently argued that market solutions to corporate governance problems are inappropriate for developing countries, because they do not have the necessary second-order institutions-lawyers, accountants, investment bankers, securities analysts, etc. - that are needed for markets to function successfully. Private ordering cannot be relied on because parties simply do not have the training and experience to bargain toward efficient arrangements. Therefore, corporate law should consist largely of mandatory, bright-line rules that are easily monitored and enforced, not vague standards and default rules. ${ }^{252}$

What an examination of Chinese institutions shows, however, is the need for a comparative institutional analysis of the type urged by Neil Komesar. ${ }^{253}$ To be sure, civil society institutions of the type that would promote market ordering in China are indeed weak. But it does not follow that institutions for state ordering can do the job any better. The key issue is that of which types of institutional reforms would yield the most bang for the buck. The policy option of simply allowing civil society institutions to do more is often overlooked in studies of corporate governance in other jurisdictions for the simple reason that few other jurisdictions impose such strict controls. But in the case of China, this area offers a great deal of room for reform.

${ }^{251}$ In the words of Ronald Gilson,

the goal is not necessarily to seek the optimal governance institutions for existing industrial conditions. Rather, reform of national governance systems should strive to assure that institutional structure facilitates prompt and low-cost organizational responses to changes in industrial technology.

Ronald J. Gilson, Path Dependence and Comparative Corporate Governance: Corporate Governance and Economic Efficiency: When Do Institutions Matter?, 74 WAsH. U. L.Q. 327, 343 (1996).

${ }^{252}$ See Paredes, supra note 20.

253 See generally KomeSAR, supra note 6. 
Table 1: Administrative sanctions against lawyers by CSRC

\begin{tabular}{|c|c|c|}
\hline Year & Nature of violation & Sanction \\
\hline 1993 & Disclosure violations in IPO & Warning \\
\hline 1996 & Disclosure violations in IPO & $\begin{array}{l}\text { Warning; fine; temporary suspension of license to do } \\
\text { securities-related work }\end{array}$ \\
\hline 1998 & $\begin{array}{l}\text { Disclosure violations in stock } \\
\text { offering }\end{array}$ & Criticism \\
\hline 1998 & $\begin{array}{l}\text { Disclosure violations in stock } \\
\text { offering }\end{array}$ & Criticism \\
\hline 1998 & Disclosure violations in IPO & $\begin{array}{l}\text { Confiscation of unlaw fully obtained income; temporary } \\
\text { suspension of license to do securities-related work }\end{array}$ \\
\hline 1999 & Disclosure violations in IPO & Warning; confiscation of unlaw fully obtained income \\
\hline 1999 & Disclosure violations in IPO & $\begin{array}{l}\text { Temporary suspension of firm's license to do securities- } \\
\text { related work; confiscation of unlawfully obtained income; } \\
\text { revocation of individual lawyer's license to do securities- } \\
\text { related work }\end{array}$ \\
\hline 1999 & Disclosure violations in IPO & $\begin{array}{l}\text { Warning; confiscation of unlaw fully obtained income; } \\
\text { warnings and fines for individual lawyer(s) who signed } \\
\text { opinion }\end{array}$ \\
\hline 2000 & Disclosure violations in IPO & $\begin{array}{l}\text { Warning; confiscation of unlaw fully obtained income; } \\
\text { warnings and fines for individual lawyer(s) who signed } \\
\text { opinion }\end{array}$ \\
\hline 2000 & Disclosure violations in IPO & $\begin{array}{l}\text { Confiscation of unlaw fully obtained income; fine of } 250,000 \\
\text { yuan; revocation of license to do securities-related work of } \\
\text { lawyer(s) who signed opinion }\end{array}$ \\
\hline 2000 & Disclosure violations in IPO & Warning to firm and individual lawyers \\
\hline 2000 & Disclosure violations in IPO & Criticism of firm and individual lawyers \\
\hline 2000 & $\begin{array}{l}\text { Incorrectly advised company } \\
\text { that CSRC approval not needed } \\
\text { for overseas IPO }\end{array}$ & $\begin{array}{l}\text { Warning; CSRC not to accept legal opinions from firm for } \\
\text { six months }\end{array}$ \\
\hline 2000 & $\begin{array}{l}\text { Issued formal opinion letter to } \\
\text { listing firm before CSRC } \\
\text { approval }\end{array}$ & $\begin{array}{l}\text { Criticism; CSRC not to accept legal opinions from firm for } \\
\text { six months }\end{array}$ \\
\hline
\end{tabular}

Source: Peng Bing, Zhengquan Lüshi Xingzheng Zeren de Shizheng Yanjiu [Empirical Research into the Administrative Liability of Securities Lawyers], FA SHANG YANJiU [STUdies IN LAW AND COMmeRCE], no. 6, 2004, at 16; author's research. 
Table 2: Enforcement actions by regulators, 1998-2003

\begin{tabular}{|c|c|c|c|}
\hline Year & $\begin{array}{c}\text { Enforcement actions taken } \\
\text { by regulatory agencies }\end{array}$ & $\begin{array}{c}\text { Of which } \\
\text { punishment }\end{array}$ & $\begin{array}{c}\text { Number of companies listed on } \\
\text { Shanghai and Shenzhen Stock } \\
\text { Exchanges }\end{array}$ \\
\hline 1998 & 3 & 3 & 853 \\
\hline 1999 & 12 & 9 & 950 \\
\hline 2000 & 16 & 7 & 1088 \\
\hline 2001 & 71 & 9 & 1160 \\
\hline 2002 & 62 & 8 & 1235 \\
\hline 2003 & 51 & 11 & 1287 \\
\hline
\end{tabular}

Source: Pistor \& Xu, supra note 203, at 33.

* "Regulatory agencies" includes the CSRC, the Shanghai and Shenzhen Stock Exchanges, and other government agencies with enforcement power.

Table 3: CSRC punishment decisions satisfying SPC conditions for private litigation, 2002-2007

\begin{tabular}{|c|c|c|}
\hline Year & $\begin{array}{c}\text { Number of punishment } \\
\text { decisions (chufa jueding) }\end{array}$ & $\begin{array}{c}\text { Of which, number satisfying } \\
\text { SPC conditions }\end{array}$ \\
\hline 2002 & 17 & 6 \\
\hline 2003 & 34 & 24 \\
\hline 2004 & 49 & 13 \\
\hline 2005 & 43 & 18 \\
\hline 2006 & 39 & 15 \\
\hline 2007 (as of Feb. 23, 2008) & 29 & 29 \\
\hline
\end{tabular}

Source: CSRC Web site, http://www.csrc.gov.cn; author's analysis. 